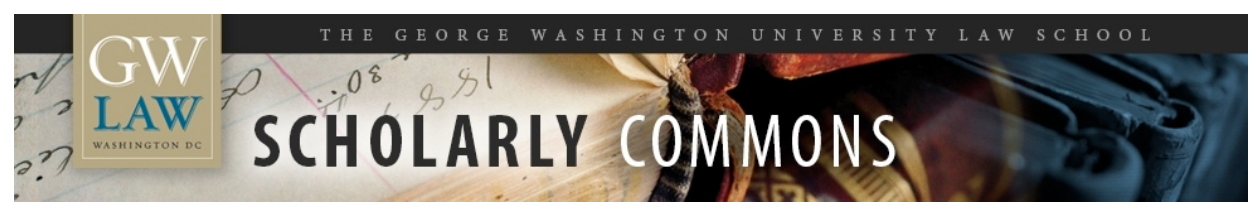

\title{
The Peter Humphrey/Yu Yingzeng Case and Business Intelligence in China
}

Donald C. Clarke

George Washington University Law School, dclarke@law.gwu.edu

Follow this and additional works at: https://scholarship.law.gwu.edu/faculty_publications

Part of the Law Commons

\section{Recommended Citation}

Clarke, Donald C., The Peter Humphrey/Yu Yingzeng Case and Business Intelligence in China (2015). Forthcoming 2015; GWU Law School Public Law Research Paper No. 2015-26; GWU Legal Studies Research Paper No. 2015-26. Available at SSRN: http://ssrn.com/abstract=2640737

This Article is brought to you for free and open access by the Faculty Scholarship at Scholarly Commons. It has been accepted for inclusion in GW Law Faculty Publications \& Other Works by an authorized administrator of Scholarly Commons. For more information, please contact spagel@law.gwu.edu. 


\title{
The Peter Humphrey/Yu Yingzeng Case and \\ Business Intelligence in China
}

\author{
Donald Clarke \\ DRAFT
}

\section{Introduction}

On August 16, 2013, the husband-and-wife investigators Peter Humphrey, a UK citizen, and Yu Yingzeng, an American citizen, were arrested in Shanghai in connection with an investigation their consulting firm, ChinaWhys, ${ }^{2}$ had been undertaking for the drug company GlaxoSmithKline ("GSK"). ${ }^{3}$ Almost exactly a year later, on August 8, 2014, the Shanghai First Intermediate People's Court found Humphrey and Yu guilty of violating Article 253, Paragraph 4 of China's Criminal Law, which criminalizes the unlawful acquisition (非法获取) of personal information of citizens (公民个人信息) (“PIC"). ${ }^{4}$ They were found to have acquired 256 items of PIC, including domicile registration information, border entry and exit records, and mobile telephone communications records. ${ }^{5}$ Humphrey was sentenced to two years and six months of

\footnotetext{
${ }^{1}$ David A. Weaver Research Professor of Law, George Washington University Law School. Address for correspondence: dclarke@law.gwu.edu. I wish to thank Jeffrey Klossner for outstanding research assistance. I am also grateful to the person who kindly provided me with a copy of the judgment in the Humphrey/Yu case.

${ }^{2}$ ChinaWhys is described on its web site as "a risk management consultancy" that provides, among other things, commercial investigation services to corporate clients. See http://chinawhys.com/peter.htm (last visited July 29, 2015).

${ }^{3}$ See David Barboza, In China, British Investigator Hired by Glaxo, and Wife, Sentenced to Prison, N.Y. Times (Aug. 8, 2014), available at http://nyti.ms/1ShcosY; Clifford Coonan, British Investigator Peter Humphrey "Regrets" Illegal Data Scam on China TV, THE INDEPENDENT (Aug. 27, 2013), available at http://ind.pn/1fI7tQ1.
}

${ }^{4}$ My information about the trial proceedings comes from my review of (a) what purports to be the transcript of the trial ("Trial Transcript") (which may or may not be complete) posted on the court's weibo (similar to Twitter) feed and available in collated form at Donald Clarke, Weibo Transcript of Peter Humphrey Trial, CHINESE LAW PROF BLOG, Aug. 8, 2014, http://bit.ly/trialtranscript, and (b) the text of the judgment of the Shanghai First Intermediate People's Court, 2014 Hu Yi Zhong Xing Chu Zi 127 Hao, Aug. 8, 2014 ("Trial Judgment"). The latter document came into my hands from a confidential source and is not posted, as it should be, on the court's web site. I believe it is authentic. Needless to say, matters stated as fact by the prosecution, the defense, or the court in the transcript and the judgment, whether related to the allegations or to the proceedings themselves, cannot be uncritically accepted as true. As of the date of this article, my source has not authorized me to release my copy of the Trial Judgment.

${ }^{5}$ See Trial Judgment, supra note 4 , at 2. 
imprisonment and fined 200,000 yuan, while Yu was sentenced to two years and fined 150,00o yuan. ${ }^{6}$ On June 9, 2015, Humphrey was formally released seven months early, apparently on grounds of ill health, ${ }^{7}$ although he was kept incommunicado for several more days. ${ }^{8}$ Yu was released at about the same time, and the couple finally left China for the UK on June $16,2015 .{ }^{9}$

The Humphrey/Yu case raises important issues both narrow and broad. The narrow issue is one that is critical for foreign, or indeed Chinese, businesses engaging in the collection of information. Some types of information gathering would be considered legitimate, normal, and lawful virtually anywhere-for example, reading newspaper reports about a rival's business strategies. ${ }^{10}$ Other types would be considered illegitimate and unlawful in virtually anywhere-for example, breaking into a rival company's safe to steal secret blueprints. The Stern Hu case, in which an employee of the Australian mining company Rio Tinto was convicted of theft of commercial secrets, raised but did not resolve this issue. ${ }^{11}$ The judgment spent a great deal of time showing that Hu had obtained information about Chinese steel companies with which Rio Tinto was

\footnotetext{
${ }^{6}$ See Barboza, supra note 3; Trial Judgment, supra note 4, at 11.

${ }^{7}$ See David Barboza, British Investigator Hired by Glaxo Is Freed From China Prison, N.Y. TIMES, June 9, 2015, available at http://nyti.ms/1Bo7A3x.

${ }^{8}$ According to a recent news report based on an interview with Humphrey,
}

Awaiting deportation, they were driven to a hotel that is unlikely to star in the Shanghai listings on TripAdvisor. It was another place of confinement.

They were installed in a room with barred windows. All the rooms around them were occupied by police officers.

"We spent a week trying to recover some of our belongings, but I was confined to the room and only Ying could go out, under police escort," he said.

"It was just a slightly more comfortable prison."

Michael Sheridan, Inside the Chinese Gulag, SUNDAY TIMES, July 20, 2015, available at http://thetim.es/1eAPonJ.

${ }^{9}$ See Sheridan, supra note 8.

${ }^{10}$ Actually, even this can be problematic in China. The prosecution in the Humphrey/Yu case accused them of "monitoring" (监控) individuals but introduced no evidence as to what the "monitoring" consisted of or why it was unlawful. The defendants contended that the prosecution had read English-language material that referred to the monitoring of individuals and meant simply following news reports, but had mistranslated the term into the more sinister-sounding 监 控. See Trial Transcript, supra note 4 .

${ }^{11}$ See Michael Sainsbury, Rio Tinto's Stern Hu Jailed for 10 Years, THE AUSTRALIAN, Mar. 29, 2010, available at http://bit.ly/1GWrOaf; John Garnaut, $A$ Year On, Secrets, Lies and Corruption Remain at the Heart of Rio Tinto Case, SYDNEY MORNING HERALD, July 6, 2010, available at http://bit.ly/1JMPQq7. 
negotiating that the companies would rather he had not obtained, but spent virtually no time showing that he had used illegal means to do so. It spoke vaguely of bribery, but $\mathrm{Hu}$ was not even charged with bribery, to say nothing of being convicted of it. ${ }^{12}$

The Humphrey/Yu case presented a similar issue. Although there was no question that the defendants had acquired information that fell within the definition of PIC, the law appropriately criminalizes acquiring PIC only when the means used are unlawful. Governments, businesses, and individuals hold vast amounts of personal information about other citizens, and the law should not and does not criminalize such holding in all cases. Consequently, it is critical for those in the business of information gathering - not an illegitimate activity per se-to know where the law draws the line. ${ }^{13}$ Regrettably, as will be discussed below, the Humphrey/Yu case sheds no light on this issue whatsoever; the court, the prosecution, and the defense all seem to have ignored it entirely. In addition, the prosecution and the court ignored an important issue as to whether Article 253 applied to the facts of this case at all.

The broad issue raised by the case is whether the Chinese legal system can be counted on to operate in a relatively fair, impersonal manner, or whether it can be used as a tool by powerful parties to punish their enemies. One of the rumors swirling around the case held that Humphrey and Yu had, in their investigations, offended a person with former ties to GSK who had powerful connections within China's political-legal apparatus (政法系统) and that the case against them was one of selective prosecution. Similar concerns were raised in the Stern Hu case: while Hu was convicted of receiving bribes, no prosecutions were ever brought against those who had given the bribes. ${ }^{14}$

This article will not attempt to assess the truth of this rumor. What it can and will do, however, is to examine all other reported convictions in Shanghai for the same offense to see if any features of the Humphrey/Yu case appear to be outliers. As will be shown, the sentences meted out to Humphrey and Yu do indeed appear to be disproportionately harsh when the underlying relevant facts are compared with those in other cases.

This article will proceed as follows. Part II will discuss the dataset on which the analysis is based. Part III will discuss legal issues in the case, in particular (a) whether Article 253 should be construed to cover the Humphrey/Yu case at all, as well as (b) the

\footnotetext{
${ }^{12}$ The text of the judgment in Chinese, as well as an imperfect but serviceable translation, can be found at Michael Sainsbury, "Conflict of Interest" in Focus in Trial of Rio Tinto's Stern Hu, THE AUSTRALIAN, April 19, 2010, available at http://bit.ly/1MSY2Zg.

${ }^{13}$ For accounts of the difficulties and dangers of doing due diligence in China, see Jane Perlez, In China, the Dangers of Due Diligence, N.Y. TIMES, Sept. 13, 2013, available at bit.ly/chinaduediligence; Kathryn Hille, Peter Humphrey Case Shows Effects of China's Tightened Privacy Laws, FinANCIAL TIMES, Aug. 29, 2013, available at http://on.ft.com/1KxYWtU; Gordon Chang, China Criminalizes Collection of Information in Glaxo Case, FORBES, Aug. 16, 2014, available at http://onforb.es/IIraake.

${ }^{14}$ See Garnaut, supra note 11.
} 
importance of the issue of unlawfulness of means when acquiring PIC and the failure of the Shanghai court to clarify, or even acknowledge the existence of, the issue. Part IV will present the results of an extensive analysis of all reported convictions in Shanghai for the crime of illegally acquiring PIC from 2009, the year this crime was written into the Criminal Law, until August 14, 2014. Part V presents a conclusion.

\section{Case Data}

In order to understand how Shanghai courts have treated legal issues and factual circumstances in other cases involving the same charges, I examined all reported trials in Shanghai on charges of unlawful acquisition of PIC between 2009, when the act became a crime, and August 14, 2014. The dataset consists of 92 cases with over 200 defendants. ${ }^{15} \mathrm{I}$ examined only Shanghai cases because while one might not expect much consistency nationwide, it is reasonable to expect consistency within a highly-developed, urban provincial-level jurisdiction such as Shanghai, and therefore gross inconsistency, if present, is less likely to be accidental. Shanghai is also the provincial-level jurisdiction with the most cases of this crime. ${ }^{16}$ The cases were examined for data about prison sentences (both fixed-term imprisonment (有期徒刑) and detention (拘留)), fines, amount of PIC acquired, the nature of the PIC, the source of the PIC, the price paid for the PIC, the means employed in acquiring the PIC, and any profits gained from the PIC.

The cases were gathered from the ChinaLawInfo legal database maintained by Beijing University. All cases were given an abbreviated English name, and all references to cases will use those English names. ${ }^{17}$ Appendix A to this article provides a full citation, in both English and Chinese, and the URL of the case on the ChinaLawInfo web site; Appendix B provides a summary of information about the cases.

\section{Did the Facts as Alleged Constitute a Crime Under Article 253?}

\section{A. Does Article 253 Apply to Humphrey and Yu at All?}

The part of Article 253 under which Humphrey and Yu were convicted was added to the Criminal Law in 2009. A close look suggests that, questions of unlawfulness of means aside, it is not even clear that the paragraphs in question were intended to apply to

\footnotetext{
${ }^{15}$ Only one of the defendants seems to have been found innocent. The vast majority received punishment of some kind. A few were explicitly declared exempt from punishment for various reasons. For a very small number of defendants (always members of a group), the judgment mentions them at the beginning but does not state their ultimate fate.

${ }^{16}$ During the period of time examined, there were ninety-two cases in Shanghai, thirty-seven in Zhejiang, twenty in Henan, nineteen in Beijing, and sixteen in Guangdong. Other provincial-level jurisdictions had fewer than ten each.

${ }^{17}$ To avoid confusion with other sources, abbreviated case names will be presented in italics (e.g., $\mathrm{Mu} 2014)$.
} 
people like them or their company. Here is Paragraph 4 of Art. 253 under which they were charged and the surrounding language; I have added the paragraph numbers.

[3] Any staff member of a state organ or an entity in such a field as finance, telecommunications, transportation, education or medical treatment who, in violation of state provisions, sells or illegally provides to others personal information on citizens that was acquired during the organ's or entity's performance of duties or provision of services, shall, if the circumstances are serious, be sentenced to fixed-term imprisonment of not more than three years or criminal detention, and/or be fined. (国家机关或者金融、电信、交通、教育、医 疗等单位的工作人员, 违反国家规定, 将本单位在履行职责或者提供服务过程中获 得的公民个人信息, 出售或者非法提供给他人, 情节严重的, 处三年以下有期徒刑 或者拘役，并处或者单处罚金。）

[4] Whoever illegally acquires the aforesaid information by stealing or any other means shall, if the circumstances are serious, be punished under the preceding paragraph. (窃取或者以其他方法非法获取上述信息, 情节严重的, 依照前款的规 定处罚。)

[5] Where an entity commits either of the crimes described in the preceding two paragraphs, it shall be fined, and the person in charge who is directly responsible and other directly responsible persons shall be punished under the applicable paragraph. (单位犯前两款罪的，对单位判处罚金，并对其直接负责的主管人员和 其他直接责任人员，依照各该款的规定处罚。)

It seems clear that this rule is aimed at cases where an organization legitimately acquires information about citizens in the course of its functions, and employees then sell this information to others behind the organization's back. That is Paragraph 3, in any case, and it applies to suppliers of information. Although the prosecution made much of Humphrey and Yu being a suppliers of personal information (to their clients), ${ }_{18}^{8}$ it seems quite a stretch to apply Paragraph 3 to them. First, they were not charged with unlawfully supplying PIC to anyone. (Somewhat troublingly, the prosecution devoted considerable time during the trial to arguing that they had done so; since the issue was entirely irrelevant to the charges brought against them, it was purely prejudicial and not probative.) Second, the organization of which they were staff members was their own company; they cannot be said to have misappropriated information from ChinaWhys.

What about Paragraph 4 ? Note that while Paragraph 4 applies to receivers of information, it is still limited to the type of information referred to in Paragraph 3: information acquired by some organization in the course of performing its functions. Thus, it does not apply to all cases in which someone illegally acquires personal information. For example, if a burglar breaks into a house and steals the homeowner's address book, that could well be deemed acquiring personal information about citizens through unlawful means, but it is not "the aforesaid information." If Paragraph 4 was

\footnotetext{
${ }^{18}$ See Trial Transcript, supra note 4.
} 
meant to cover PIC in general, it is hard to understand why it does not simply say so, instead of saying "the aforesaid information."

It is of course possible that Humphrey and Yu acquired some personal information through illegal means, but neither the transcript nor the judgment show any effort by the prosecution or the court respectively to show that it was in the category of information “acquired during the organ's or entity's performance of duties or provision of services".

In 2013, the Supreme People's Court, the Supreme People's Procuracy, and the Ministry of Public Security issued a joint notice ${ }^{19}$ about this particular crime, but it does not change the above analysis. If anything, it underscores the point that the revised Art. 253 was about something quite different from what Humphrey and Yu were doing. It was about the problem of employees of various institutions that hold a great deal of personal information selling that information on a massive scale to middlemen, who would then resell it to "illegal" investigative companies for purposes such as "illegal" debt collection. (I do not know where the line between legal and illegal is in the above cases.)

Duan Wanjin, a lawyer for Humphrey, in fact argued that the source of the information did not meet the requirements of the law; ${ }^{20}$ neither the prosecution nor the court addressed the argument, even just to dismiss it. But although this failure to address the issue is unfortunate, it does not appear to be unusual in the Shanghai court system. Even though there is very respectable scholarly support for the narrow reading of "the aforesaid information," ${ }^{21}$ no Shanghai court has adopted this reading. Instead, they have adopted an expansive view that equates "the aforesaid information" with PIC tout court, and have held defendants criminally liable even where there was no finding on the source of the information. ${ }^{22}$

\footnotetext{
${ }^{19}$ Supreme People’s Court, Supreme People's Procuratorate \& Ministry of Public Security (最高人 民法院、最高人民检察院、公安部), Notice on Punishing According to Law Criminal Activities that Infringe on Citizens' Personal Information (关于依法惩处侵害公民个人信息犯罪活动的通知 ), promulgated April 23, 2013, http://www.law-lib.com/law/law_view.asp?id=429958.

${ }^{20}$ See Trial Transcript, supra note 4, Part 20.

${ }^{21}$ See Zhao Bingzhi (赵秉志) \& Wang Dongyang (王东阳), We Should Protect Human Rights Even More in the Information Age (信息时代更应强化人权保障), LEGAL SYSTEM DAILY (法制日报), March 4, 2009, reprinted at http://bit.ly/1ShxWWB (Sohu news site) ("[F]or example, if [the actor] uses web technology or other methods illegally acquires personal information from the individual citizen, even if the amount of unlawfully acquired information is huge, it cannot be considered to constitute this crime.").

${ }^{22}$ For an academic view advocating this broader reading that dispenses with the inquiry into source, see Wang Zhaowu (王昭武) \& Xiao Kai (削凯), Several Issues in Determining the Crime of Infringing Upon Citizens' Personal Information (侵犯公民个人信息犯罪认定中的若干问题), JURISPRUDENCE (法学), no. 12, 2009, at 146, 149.
} 


\section{B. What Constitutes "Personal Information of Citizens"?}

Three views exist among Chinese legal scholars as to what constitutes PIC. One view defines PIC as any information that enables one to discern the individual identity of a person-for example, name, occupation, position, age, marital status, education, professional qualifications, work experience, address, telephone number, credit card number, finger prints, or online username and password. ${ }^{23} \mathrm{~A}$ broader interpretation defines PIC as any information, existing in any format, that relates to a person and that can also identify a specific individual — that is, any information, data, or circumstances concerning a person. ${ }^{24} \mathrm{~A}$ third view limits PIC to information closely related to citizenship and personality, owned by the person, unrelated to public life, and unknown to the general public. ${ }^{25}$ This last view incorporates a kind of expectation-of-privacy analysis into the definition of PIC, with four theories on how the expectation could be established: (1) a pure subjective test; (2) a pure objective test; (3) a mixed test, where there must be both an objective and actual subjective expectation of privacy; and (4) a disjunctive test, where either a subjective or an objective expectation of privacy is sufficient.

The Shanghai courts appear to have adopted the broadest definition: any information concerning a person is PIC for purposes of paragraph 4. No Shanghai case has inquired into expectation of privacy. The Humphrey/Yu case does not appear to be unusual in this respect.

\section{The Requirement of Unlawfulness of Method}

One of the most disturbing aspects of the proceedings is the almost complete lack of attention paid to a critical element of the crime with which Humphrey and Yu were charged: the element of unlawfulness in the collection of information. Note that while Paragraph 3 of Article 253 covers those who supply PIC, it does not cover those who acquire it. Only Paragraph 4 does that, ${ }^{26}$ and it covers only the unlawful acquisition of PIC.

In the vast majority of cases in the dataset, covering 139 defendants, the PIC was acquired by purchase. With seventeen defendants, the PIC was traded for other PIC. With six defendants, the PIC was acquired by theft. With four defendants, the PIC was acquired by stalking a particular individual. And with three defendants, the PIC was acquired through some kind of trick. Thirty-one defendants were found to have "acquired" (获取) PIC without a discussion of method. In those cases, the court usually used the phrased "unlawfully acquired," without any discussion of the unlawfulness.

\footnotetext{
${ }^{23}$ See Huang Taiyun (黄太云), An Interpretive Reading of the Seventh Amendment to the Criminal Law (刑法修正案(七)解读), PEOPLE'S PROCURATORATE (人民检察), no. 6, 2009, at 5, 15.

${ }^{24}$ See Wang \& Xiao, supra note 22, at 147.

${ }^{25}$ See Wang \& Xiao, supra note 22, at 147.

${ }^{26}$ Paragraph 5 of Article 253 merely duplicates the effect of Paragraphs 3 and 4 as applied to entities other than individuals.
} 
Because Paragraph 4 does not criminalize the mere acquisition of PIC but attaches a condition of illegality to the method, it is necessary to figure out what methods are illegal. Although Paragraph 3 makes selling PIC illegal under the conditions stated, Paragraph 4 mentions only theft, but not purchase or mere receipt. ${ }^{27}$ No doubt acquiring PIC by fraud or hacking would be covered, assuming the specific acts in question were per se illegal. ${ }^{28}$ Nevertheless, Shanghai courts have in many cases found defendants guilty of unlawful acquisition where the information was purchased, without a specific finding that the purchase was in some way unlawful.

This murkiness surrounding the requirement of unlawfulness represents a significant threat to anyone engaged in the business of collecting information, even for purposes generally considered legitimate. For example, although legal scholars did not expect Paragraph 4 to reach creditors seeking to locate debtors, ${ }^{29}$ Shanghai courts have found private investigators engaged in debt collection activities guilty under Paragraph 4 without any inquiry into the lawfulness of their methods. ${ }^{30}$

Although the failure of Shanghai courts in general and the Humphrey/Yu court in particular to shed any helpful light on the issue of unlawfulness of method is regrettable, it is nevertheless not unusual, and so the Humphrey/Yu case cannot be considered an outlier in that respect. Still, the court's treatment of the facts warrants discussion.

Although there was very little disagreement about the facts in this case, much of the trial-well over half-was devoted to establishing things that were not really in question. The critical question is what the legal effect of those facts should be.

For example, the prosecution devoted some time to establishing that ChinaWhys's projects had code names. What this has to do with the charges was not made clear. The prosecution also apparently thought the following facts needed to be established and were important:

- The defendants or their agents had bought and sold information. The prosecution's main accusation was that the defendants had paid Zhou Hongbo, Liu $\mathrm{Yu}$, and Cai Zhicheng from 800 to 2,00o yuan per item for a total of 256 items of PIC, including information about domicile registration, border entry and exit

\footnotetext{
${ }^{27}$ Two commentators have suggested that a purchaser could be liable under Paragraph 3 on a theory of accomplice or co-conspirator liability for the seller's violation, but this does not make liability under Paragraph 4 any clearer. See Wang \& Xiao, supra note 22, at 152-53.

${ }^{28}$ See Li Ziping (利子平) \& Zhou Jianda (周建达), A Preliminary Discussion of “Serious Circumstances" in the Crime of Unlawful Acquisition of the Personal Information of Citizens (非法 获取公民个人信息罪“情节严重”初论), JURISPRUDENCE REVIEW (法学评论), no. 175, 2012, at 146, 15152.

${ }^{29}$ See Wang \& Xiao, supra note 22, at 153.

${ }^{30}$ See, e.g., Xue 2012, $X X X 2012 b$.
} 
records, and mobile telephone numbers, ${ }^{31}$ and had then after compiling investigation reports sold this information to clients. ${ }^{32}$

- The defendants or their agents had hired people to watch a target. (Note that as far as the evidence showed, the watching involved someone sitting outside the target's office for three hours.)

- The defendants had followed (跟踪) people.

- The defendants had “monitored" (监控) people. (No evidence was introduced on this point; the defense's response was that the prosecution got this idea from a misunderstanding of the term "monitoring" used in ChinaWhys's reports, where it simply meant things like tracking news about a company or individual.)

- The defendants had hired a non-mainland (境外) company to engage in following and monitoring targets. (This was part of the prosecution's legal argument and was not supported by any evidence introduced in the factual part of the trial.)

- The defendants or their agents had pretended to be relatives or clients of various people when seeking information.

- The defendants had, between January 2009 and June 2013, performed consulting services for 78 clients and received almost 21 million yuan in fees. Some specific clients-not including GSK-were named in the judgment. ${ }^{33}$

- The defendants had an illegal purpose in collecting the information. (The prosecution didn't say what that purpose was; the defense argued out that their purpose was to conduct their business and was not illegal.)

The prosecution did not, however, make any argument or cite any authority in support of its assertion that these methods were illegal. Nevertheless, the court seems to have taken it for granted that these methods are indeed illegal. Indeed, in the judgment, the court specifically says, "The two [defendants] knew that to acquire personal information of citizens by means of purchase is unlawful." ${ }^{34}$ This is of tremendous significance. If buying and selling cell phone numbers is illegal, for example, then millions of individuals and companies in China are criminals.

The response of the defense to this issue of illegality of methods seemed ambivalent. In some places in the transcript, it argued that what the defendants did was to pay for investigative services, which is not prohibited by law. Thus, the requirement of illegality of method was not met. Elsewhere, though, the defense made what seem to be astonishing concessions. According to the judgment, the defense conceded that the acts

\footnotetext{
${ }^{31}$ See Trial Judgment, supra note 4, at 2.

${ }^{32}$ Note, however, that Humphrey and Yu were not formally charged with the unlawful sale of PIC.

33 See Trial Judgment, supra note 4, at 5-6.

${ }^{34}$ See Trial Judgment, supra note 4 , at 9.
} 
in question were unlawful, but argued that the defendants did not know they were unlawful at the time and that the circumstances were not serious. ${ }^{35}$ The transcript quotes one of the defendants' attorneys, Zhai Jian, as saying, "The acts of the defendants in this case are unlawful, because neither individuals nor commercial entities have the right to acquire citizens' personal information about their families, their entering and leaving the country, and their mobile phone communications via the method of paying for it." ${ }^{36} \mathrm{He}$ goes on to say that in pre-trial conferences with the defendants, he has ascertained that in their own countries, information on entering and leaving the country as well as mobile phone communications are considered strictly private, and "therefore the defendants' collecting of such information is unlawful." 37

This argument seems questionable in a number of respects. First and most obviously, what other countries do cannot determine Chinese law, although obviously it bears on whether the defendants thought they were doing something wrong. Second, this statement conflates the issue of what counts as PIC with the issue of whether collecting it is unlawful. Art. 253 criminalizes only the unlawful collection of PIC, so deciding that something should be considered PIC does not end the inquiry into criminal liability.

Third, and most important, Zhai is as silent as the prosecution on the source for his statement about the applicable law. It is sometimes said in jest that in China, everything not specifically permitted is forbidden, but this really is nothing more than a jest. No legal system could possibly function this way. Chinese law does not specifically permit any of the million actions we take every day, from brushing our teeth to watching Korean soap operas; this does not make us criminals. A statement that it is unlawful to do something needs support. Again, if Zhai and the prosecution are right about this, China is awash in criminals whose offenses are far worse than those of Peter Humphrey and Yu Yingzeng.

\section{Are the Humphrey/Yu Sentences Exceptional Compared with Other Shanghai Cases?}

\section{A. Introduction}

This part of the article presents the results of an analysis of the case dataset with a focus on the sentences. As will be discussed in more detail below, I conclude that while gaps in information make certainty impossible, the weight of the evidence suggests that the sentences imposed on Humphrey and $\mathrm{Yu}$ - Humphrey was given a heavier sentence

\footnotetext{
${ }^{35}$ See Trial Judgment, supra note 4, at 3. On the relevance of serious circumstances, see the discussion in Part IV.B, infra. Confusingly, the judgment at one point seems to say that the defendants admitted they knew that it was unlawful to purchase PIC. See Trial Judgment, supra note 4 , at 9 .

${ }^{36}$ Trial Transcript, supra note 4, Part 26.

37 Trial Transcript, supra note 4, Part 26.
} 
than any other defendant in the entire dataset-were far out of line with sentences imposed on other defendants when the relevant facts are compared. At the very least, the analysis supports shifting the burden of argument and proof to those who would assert that the trial was fair and the sentences proportionate.

\section{B. The Question of "Serious Circumstances" 1. In general}

Even if all the factual predicates for the crime are present, it is not clear that they rise to the level of criminality under the Criminal Law. This is because Chinese criminal law has a general rule (Art. 13) that an act is not a crime where "the circumstances are clearly minor and the harm is not great” (情节显著轻微危害不大). In addition, both Paragraph 3 and Paragraph 4 explicitly contain a requirement of serious circumstances.

Sometimes the Supreme People's Court will come up with an interpretation of what constitutes "serious circumstances" in particular crimes. Unfortunately, there is no such interpretation or other official guidance available here. Among Chinese scholars, there are varying views as to what constitutes "serious circumstances" under Article 253. Among the candidate factors are (1) a large quantity of PIC; (2) illegal purpose; (3) severe or malicious means; (4) severe harm to a person (bodily, economic, social, or emotionalfor example, when suicide results); (5) multiple infringements; (6) social disruption; (7) where PIC leaves the country; (8) multiple victims; (9) large profits; (10) forming an illegal network for the procurement and distribution of PIC; (11) the amount paid for PIC; (12) multiple PIC-related convictions; (13) criminal use; (14) nature of PIC (for example, financial, medical, or marital); and (15) acquiring PIC of disabled persons or illegitimate children. ${ }^{38}$

\section{2. "Serious circumstances" in the dataset}

Academic analyses are one thing, judicial practice another. In practice, courts in the dataset rarely analyzed the issue of serious circumstances and offered only a conclusory statement that the circumstances were serious. Twenty-three cases, however, did mention something extra in the section of the judgment finding serious circumstances. The circumstances mentioned in these cases included joint commission, purchase, online purchase, collective purchase, purchase of a large amount of PIC, profits, and (mysteriously) "other means," suggesting that these constitute serious circumstances. ${ }^{39}$ One of the more specific cases mentioned collective acquisition and sale of PIC..$^{40}$ Two cases specified "violation of state law." ${ }^{41}$ Some cases mentioned the sheer

${ }^{38}$ See Li \& Zhou, supra note 28 , at 146-47, and sources cited therein.

${ }^{39}$ See, e.g., Zhou 2014 (purchasing); Mu 2014 (collective unlawful purchase); Shanghai $2013 a$ (collective purchasing); Chen 2014 (using other means to unlawfully purchase PIC); Wang $2013 \mathrm{C}$ (other means); Lu 2014 (online purchase); Chen 2013a (large purchase); Liu 2013a (profit from PIC acquisition).

${ }^{40}$ See, e.g., Ye 2013 (collective unlawful acquisition and sale of PIC); Zhu 2012a (purchase and sale). 
volume of PIC collected. ${ }^{42}$ Two cases mentioned illegal purchase, ${ }^{43}$ although they may have been simply declaring that any purchase was illegal.

Many cases did indeed involve circumstances that might fairly be deemed serious. In several cases, the defendant made a large profit from the sale of PIC, ${ }^{44}$ or the defendant was engaged in the business of collecting and distributing PIC. ${ }^{45}$ In general, in cases where a large amount of PIC was involved, the courts found it less necessary to discuss other serious circumstances.

Overall, the general picture that emerges from the dataset regarding the requirement of serious circumstances is that (a) judgments rarely discuss the "serious circumstances" requirement specifically, preferring to rely on conclusory statements, and (b) judgments do mention various facts about the case that might constitute grounds for finding the presence of serious circumstances, even though they are not specifically labelled as such.

The following discussion presents an analysis of the dataset in tabular form. It examines in detail only cases with prison sentences of one year or more, because the standards the Shanghai courts appear to employ are clearer in these cases. Cases featuring sentences of less than one year, and especially sentences of six months or less, vary a great deal in their facts, and it is difficult to make meaningful inferences. The information, however, is all compiled in Appendix B.

Tables 1, 2, and 3 show cases where the sentence was a prison term of 12 months, 13-17 months, and 18-24 months respectively. Although the maximum term is 36 months, no defendant other than Peter Humphrey was sentenced to more than 24 months (Humphrey was sentenced to 30 months). Table 4 shows cases involving private investigators or persons engaging in similar activities. In addition to the case name, prison term, and fine, each table sets forth the amount of PIC, the nature of the PIC, the means of acquisition, and any serious circumstances.

\section{a) Table 1}

In general, when the quantity of PIC is less, there are usually more serious circumstances present that justify a heavy sentence. For example, Qian 2014 involved a public official, and the PIC was used for harassment and intimidation. In Hua 2013, the amount of PIC involved was modest, but the profit was relatively large. On the other

\footnotetext{
${ }^{41} \mathrm{XXX} 2012 a$ (in contravention of state laws and regulations); $X X X 2012 b$ (same).

${ }^{42}$ Zhou 2010 (“The number of PIC is so large that circumstances are serious (数量之大情节严重).”); Lan 2011 (same).

${ }^{43} \mathrm{Wu} 2012$ (illegal purchase); Chen 2012 (same).

${ }^{44}$ See, e.g., Lu 2014; Ye 2013; Zhu 2012 b.

${ }^{45}$ See, e.g., Wu 2013; Lu 2013b; XXX 2012a; Hou 2012.
} 
hand, in Shanghai 2012, the circumstances were not as serious, but there was a large amount of PIC involved.

Note that in Ye 2013 and Zhu 2012b, Table 1 shows only accomplices sentenced to one-year prison terms, whereas the principals are found in Table 3 , having each received terms of 18 months. 
Table 1: Prison sentence of 12 months (arranged in ascending order of amount of PIC)

\begin{tabular}{|c|c|c|c|c|c|}
\hline Case & Fine & PIC Amount & Nature of PIC & Means & $\begin{array}{l}\text { Serious } \\
\text { Circumstances }\end{array}$ \\
\hline Qian 2014 & 2,000 & Individuals & $\begin{array}{l}\text { Information on } \\
\text { government } \\
\text { officials }\end{array}$ & Acquired & $\begin{array}{l}\text { Acquired from } \\
\text { public } \\
\text { official/police } \\
\text { officer; used for } \\
\text { harassment and } \\
\text { intimidation }\end{array}$ \\
\hline Chen 2011b & 12,000 & Unclear & Real estate. & Acquired & Unclear \\
\hline Hua 2013 & 5,000 & $\begin{array}{l}20 \\
\text { individuals }\end{array}$ & $\begin{array}{l}\text { ID, financial, real } \\
\text { estate, bank } \\
\text { account \#, vehicle } \\
\text { registration, etc. of } \\
\text { specific individuals }\end{array}$ & Purchased & 50,900 yuan profit \\
\hline Lai 2010 & 10,000 & 40 & $\begin{array}{l}\text { Individual } \\
\text { whereabouts }\end{array}$ & Purchased & $\begin{array}{l}\text { Private } \\
\text { investigator; } \\
\text { 40,ooo yuan profit; } \\
\text { paid for on per-PIC } \\
\text { basis; targeted } \\
\text { specific individuals }\end{array}$ \\
\hline Huo 2012 & 20,000 & 59 & $\begin{array}{l}\text { Phone records; } \\
\text { census data; hotel } \\
\text { registration; flight } \\
\text { information; } \\
\text { immigration } \\
\text { records; phone } \\
\text { location }\end{array}$ & Purchased & $\begin{array}{l}\text { Private } \\
\text { investigator/PIC } \\
\text { business }\end{array}$ \\
\hline $\mathrm{XXX} 2012 \mathrm{~b}$ & 2,000 & 195 & $\begin{array}{l}\text { Locational info: } \\
\text { corporate } \\
\text { registration; hotel } \\
\text { registration; car } \\
\text { registration; flight } \\
\text { information; etc. }\end{array}$ & $\begin{array}{l}\text { Purchased } \\
\text { from illegal } \\
\text { supplier }\end{array}$ & $\begin{array}{l}\text { Private } \\
\text { investigator/debt } \\
\text { collection }\end{array}$ \\
\hline Liu 2014 & 10,000 & 10,153 & Client info & Received & $\begin{array}{l}\text { Paid 20,00o for } \\
\text { PIC; insurance PIC. }\end{array}$ \\
\hline Han 2013 & 20,000 & 40,161 & $\begin{array}{l}\text { ID, financial, real } \\
\text { estate, bank } \\
\text { account \#, vehicle } \\
\text { registration, etc. of } \\
\text { specific individuals }\end{array}$ & Purchased & For profit \\
\hline
\end{tabular}




\begin{tabular}{|c|c|c|c|c|c|}
\hline Ye 2013 & 15,000 & 83,908 & Finance & Purchased & $\begin{array}{l}\text { Accessory; 230,000 } \\
\text { yuan profit }\end{array}$ \\
\hline Ye 2013 & 15,000 & 83,908 & Finance & Purchased & $\begin{array}{l}\text { Accessory; 230,000 } \\
\text { yuan profit. }\end{array}$ \\
\hline Ye 2013 & 15,000 & 83,908 & Finance & Purchased & $\begin{array}{l}\text { Accessory; 300,000 } \\
\text { yuan profit }\end{array}$ \\
\hline Zhu 2012b & 10,000 & 136,727 & Purchase orders & Received & $\begin{array}{l}\text { Accessory; 100,000 } \\
\text { profit }\end{array}$ \\
\hline Zhu 2012b & 10,000 & 136,727 & Purchase orders & Received & $\begin{array}{l}\text { Accessory; 100,000 } \\
\text { profit }\end{array}$ \\
\hline Zhu 2012b & 10,000 & 136,727 & Purchase orders & Received & $\begin{array}{l}\text { Accessory; 100,000 } \\
\text { profit }\end{array}$ \\
\hline Xing 2014 & 5,000 & 198,187 & Contact & Acquired & For profit \\
\hline Zhou 2010 & 20,000 & 980,000 & $\begin{array}{l}\text { Info on wealthy } \\
\text { individuals }\end{array}$ & Acquired & $\begin{array}{l}\text { Principal; sold for } \\
\text { profit }\end{array}$ \\
\hline Chen 2014 & 2,000 & $\begin{array}{l}\text { "several } \\
\text { million" }\end{array}$ & Unclear & Trick & Criminal sale \\
\hline $\begin{array}{l}\text { Shanghai } \\
2012\end{array}$ & 5,000 & $90,000,000$ & $\begin{array}{l}\text { Contact; bank; } \\
\text { infant; consumer } \\
\text { records }\end{array}$ & Purchased & $\begin{array}{l}\text { For profit; paid } \\
2,500,000 \text { for PIC }\end{array}$ \\
\hline $\begin{array}{l}\text { Shanghai } \\
2012\end{array}$ & 10,000 & 90,000,000 & $\begin{array}{l}\text { Contact; bank; } \\
\text { infant; consumer } \\
\text { records }\end{array}$ & Purchased & $\begin{array}{l}\text { For profit; paid } \\
2,500,000 \text { for PIC }\end{array}$ \\
\hline
\end{tabular}

\section{b) Table 2}

Here we see the same pattern as in Table 1. Where serious circumstances are lacking, there is generally a large amount of PIC involved. For example, Mou 2014, Lan 2011, and Deng 2014 all involved a large amount of PIC but with seemingly no other serious circumstances. There are defendants here who were the accessories to the unlawful acquisition. ${ }^{46}$ The principals in those cases received heavier sentences.

\footnotetext{
${ }^{46}$ See Mu 2014; Shanghai $2013 a$.
} 
Table 2: Prison sentence of 13-17 months (arranged in ascending order of length of sentence)

\begin{tabular}{|c|c|c|c|c|c|c|}
\hline Case & Term & Fine & PIC Amount & Nature & Means & $\begin{array}{l}\text { Serious } \\
\text { Circum- } \\
\text { stances }\end{array}$ \\
\hline Mou 2014 & 13 & 5,000 & 50,000 & Unclear & Purchased & For profit \\
\hline Mou 2014 & 13 & 5,000 & 59,000 & Unclear & Purchased & For profit \\
\hline Lan 2011 & 14 & 10,000 & $6,246,842$ & Unclear & $\begin{array}{l}\text { Purchased } \\
\text { or traded }\end{array}$ & $\begin{array}{l}\text { For profit; } \\
\text { paid } 3,400 \\
\text { for PIC }\end{array}$ \\
\hline Li 2013a & 14 & 20,000 & 71,158 & Unclear & Purchased & $\begin{array}{l}\text { Sold for } \\
\text { profi }\end{array}$ \\
\hline Deng 2014 & 14 & 4,000 & 250,000 & $\begin{array}{l}\text { Public exam } \\
\text { participants }\end{array}$ & Purchased & For profit \\
\hline Zhu 2012a & 15 & 30,000 & 2,000 & Finance & Purchase. & $\begin{array}{l}20,000 \\
\text { profit; paid } \\
10-100 \text { for } \\
\text { PIC }\end{array}$ \\
\hline Zhu 2012a & 15 & 30,000 & 1,000 & Finance & Purchased & $\begin{array}{l}30,000 \\
\text { profit; paid } \\
10-100 \text { for } \\
\text { PIC }\end{array}$ \\
\hline Lu $2014^{47}$ & 15 & 20,000 & $\begin{array}{l}\text { Specific } \\
\text { individuals. }\end{array}$ & $\begin{array}{l}\text { Specific } \\
\text { individuals }\end{array}$ & Purchased & $\begin{array}{l}\text { Sold for } \\
43,400 \text { profit }\end{array}$ \\
\hline $\mathrm{Mu} \mathrm{2014^{48 }}$ & 15 & 20,000 & 70,000 & $\begin{array}{l}\text { Telecomm } \\
\text { client list }\end{array}$ & Received & $\begin{array}{l}\text { Accessory; } \\
\text { fraud; } \\
\text { caused } \\
\text { economic } \\
\text { loss of } \\
733,305 \text { to } \\
3^{\text {rd }} \text { party }\end{array}$ \\
\hline Mu 2014 & 15 & 20,000 & 70,000 & $\begin{array}{l}\text { Telecomm } \\
\text { client list }\end{array}$ & Received & $\begin{array}{l}\text { Accessory; } \\
\text { fraud; } \\
\text { caused }\end{array}$ \\
\hline
\end{tabular}

47 The defendant here purchased PIC of specific individuals and sold them for profit on line. The PIC included the census data of Raymond Chan (陈旭明), a Hong Kong voice actor, bank information of, among others Jian Yifeng (江一峰), a prominent radiologist, and the bank account numbers of Wang Wen (王雯), a well-known singer.

${ }^{48}$ The principal in this case was sentenced to two years of imprisonment. 


\begin{tabular}{|l|l|l|l|l|l|l|}
\hline & & & & & & $\begin{array}{l}\text { economic } \\
\text { loss of } \\
733,305 \text { to } \\
3^{\text {rd }} \text { party }\end{array}$ \\
\hline $\begin{array}{l}\text { Shanghai } \\
\text { 2013a } 49\end{array}$ & 16 & 30,000 & $6,000,000$ & $\begin{array}{l}\text { Frequent flier } \\
\text { miles info }\end{array}$ & Purchased & $\begin{array}{l}\text { Accessory; } \\
\text { for profit; } \\
\text { paid } \\
\text { 20o,ooo for } \\
\text { PIC }\end{array}$ \\
\hline Han 2014 & 16 & 3,000 & 160,000 & Unclear & Acquired & $\begin{array}{l}\text { For profit; } \\
\text { acquired } \\
\text { from } \\
\text { workplace }\end{array}$ \\
\hline Han 2014 & 16 & 3,000 & 160,000 & Unclear & Received & For profit \\
\hline Lan 2011 & 17 & 15,000 & $16,823,533$ & Unclear & $\begin{array}{l}\text { Purchased } \\
\text { or traded }\end{array}$ & \begin{tabular}{l} 
For profit \\
\hline
\end{tabular} \\
\hline
\end{tabular}

\section{c) Table 3}

Here, almost every case has serious circumstances coupled with a large amount of PIC. In addition, there are seven principals here and only one accessory. In the case of the accessory in $\mathrm{Mu}$ 2014, there were additional serious circumstances that warranted a heavy sentence.

Most important, however, are the heaviest sentences. For cases where the prison term was twenty months or more, either the amount of PIC involved was enormous or there were very serious circumstances. There are no private investigator cases in Table 3, and that the lowest amount of PIC involved is 70,00o items.

Table 3: Prison sentence of 18-24 months (arranged in ascending order of length of sentence)

\begin{tabular}{|l|l|l|l|l|l|l|}
\hline Case & Term & Fine & PIC Amount & Nature & Means & $\begin{array}{l}\text { Serious } \\
\text { circum- } \\
\text { stances }\end{array}$ \\
\hline Lan 2011 & 18 & 15,000 & $16,823,533$ & $\begin{array}{l}\text { Purchase } \\
\text { orders }\end{array}$ & $\begin{array}{l}\text { Purchased or } \\
\text { traded }\end{array}$ & $\begin{array}{l}\text { For profit; } \\
\text { paid 3,40o for } \\
\text { PIC }\end{array}$ \\
\hline $\begin{array}{l}\text { Shanghai } \\
2012\end{array}$ & 18 & 20,000 & $90,000,000$ & $\begin{array}{l}\text { Contact; bank; } \\
\text { infant; } \\
\text { consumer } \\
\text { records }\end{array}$ & Purchased & $\begin{array}{l}\text { For profit; } \\
\text { paid } \\
2,500, \text { ooo for } \\
\text { PIC }\end{array}$ \\
\hline
\end{tabular}

${ }^{49}$ The two principals in this case were sentenced to 18 months and 20 months of imprisonment respectively. 
Draft date: Aug. 5, 2015

\begin{tabular}{|c|c|c|c|c|c|c|}
\hline Ye 2013 & 18 & 50,000 & 83,908 & Finance & $\begin{array}{l}\text { Purchased/ or } \\
\text { stolen }\end{array}$ & $\begin{array}{l}\text { Principal; } \\
\text { 1,500,00o } \\
\text { profit }\end{array}$ \\
\hline $\begin{array}{l}\text { Shanghai } \\
\text { 2013a }\end{array}$ & 18 & 40,000 & $6,000,000$ & $\begin{array}{l}\text { Frequent flier } \\
\text { miles inf }\end{array}$ & Purchased & $\begin{array}{l}\text { Principal; for } \\
\text { profit; paid } \\
\text { 200,ooo for } \\
\text { PIC }\end{array}$ \\
\hline Long 2014 & 18 & 20,000 & $100,000,000$ & Unclear & Purchased & $\begin{array}{l}\text { 4,ooo profit; } \\
\text { paid 4,00o } \\
\text { for PIC }\end{array}$ \\
\hline Tang 2014 & 18 & 5,000 & $12,857,019$ & Contact & Purchased & For profit \\
\hline Zhu 2012b & 18 & 30,000 & 136,727 & Unclear & Acquired & $\begin{array}{l}\text { Principal; } \\
\text { 100,o00 profit }\end{array}$ \\
\hline Zhu 2012b & 18 & 30,000 & 136,727 & $\begin{array}{l}\text { Purchase } \\
\text { orders }\end{array}$ & Received & $\begin{array}{l}\text { Principal; } \\
\text { 100,o0o profit }\end{array}$ \\
\hline $\begin{array}{l}\text { Deng } \\
2014\end{array}$ & 18 & 5,000 & 450,000 & $\begin{array}{l}\text { Participants in } \\
\text { public } \\
\text { examination }\end{array}$ & Purchased & Fraud \\
\hline $\mathrm{Mu} 2014$ & 18 & 20,000 & 70,000 & $\begin{array}{l}\text { Telecomm } \\
\text { client list }\end{array}$ & Received & $\begin{array}{l}\text { Accessory; } \\
\text { fraud; caused } \\
\text { economic } \\
\text { loss of } \\
733,305 \text { to } 3^{\text {rd }} \\
\text { party }\end{array}$ \\
\hline $\begin{array}{l}\text { Shanghai } \\
\text { 2013a }\end{array}$ & 20 & 50,000 & 6,000,000 & $\begin{array}{l}\text { Frequent flier } \\
\text { miles info }\end{array}$ & Purchased & $\begin{array}{l}\text { Principal; for } \\
\text { profit; paid } \\
\text { 20o,ooo for } \\
\text { PIC }\end{array}$ \\
\hline Long 2014 & 21 & 20,000 & $100,000,000$ & Unclear & Acquired & $\begin{array}{l}\text { 4,ooo profit; } \\
\text { paid } 5,500 \text { for } \\
\text { PIC }\end{array}$ \\
\hline Zhou 2010 & 24 & 40,000 & $30,000,000$ & $\begin{array}{l}\text { Info on wealthy } \\
\text { individuals }\end{array}$ & Acquired & Principal \\
\hline $\begin{array}{l}\text { Shanghai } \\
2012\end{array}$ & 24 & 20,000 & $90,000,000$ & $\begin{array}{l}\text { Contact; bank; } \\
\text { infant; } \\
\text { consumer } \\
\text { records }\end{array}$ & Purchased & $\begin{array}{l}\text { For profit; } \\
\text { paid } \\
2,500,000 \text { for } \\
\text { PIC }\end{array}$ \\
\hline Mu 2014 & 24 & 30,000 & 70,000 & $\begin{array}{l}\text { Telecomm } \\
\text { client list }\end{array}$ & Purchase & $\begin{array}{l}\text { Principal; } \\
\text { fraud; caused } \\
\text { economic } \\
\text { loss of } \\
733,305 \text { to } 3^{\text {rd }}\end{array}$ \\
\hline
\end{tabular}




\begin{tabular}{|l|l|l|l|l|l|l|}
\hline & & & & & & party \\
\hline
\end{tabular}

\section{3. "Serious circumstances" in the Humphrey/Yu case}

In the Humphrey/Yu case, the defendants' lawyers argued that the requirement of "serious circumstances" was not met; the prosecution argued that it was. The relevant facts apparently involved how many items of personal information were acquired, the purpose for which they were acquired, whether the defendants made a lot of money, and the general social danger of their activities.

The arguments made during the trial in the Humphrey/Yu case about facts and their significance break down roughly as follows: ${ }^{50}$

\begin{tabular}{|l|l|l|}
\hline Issue & Prosecution & Defense \\
\hline $\begin{array}{l}\text { Amount of } \\
\text { information } \\
\text { acquired }\end{array}$ & $\begin{array}{l}\text { A large amount: 256 } \\
\text { items. }\end{array}$ & A small amount: 256 items. ${ }^{\text {11 }}$ \\
\hline Motivation & To make money. & $\begin{array}{l}\text { 1. Of course to make money; we were a business. } \\
\text { 2. To contribute to anti-corruption efforts. In } \\
\text { about 90\% of the cases investigated, initial } \\
\text { suspicions turned out to be accurate. }\end{array}$ \\
\hline $\begin{array}{l}\text { Amount of } \\
\text { money made }\end{array}$ & $\begin{array}{l}\text { "Huge" (citing gross } \\
\text { revenues). }\end{array}$ & $\begin{array}{l}\text { It is misleading to look at gross revenues; one } \\
\text { must deduct costs. }\end{array}$ \\
\hline Social danger & $\begin{array}{l}\text { What kind of society } \\
\text { would it be if people } \\
\text { could be watched and } \\
\text { followed 24 hours a day, } \\
\text { with secret photos taken } \\
\text { of them?52 }\end{array}$ & $\begin{array}{l}\text { There was actually very little personal } \\
\text { information taken, that which was taken was not } \\
\text { all passed on to clients in reports, and that which } \\
\text { was passed on was not used for bad purposes. } \\
\text { The defense also noted that some of the } \\
\text { prosecution's claims had no foundation in any } \\
\text { evidence they brought before the court. There } \\
\text { was, for example, a single instance of following } \\
\text { someone. Someone was stationed outside the } \\
\text { target's office for three hours. The prosecution's } \\
\text { evidence showed nothing else. No evidence of } \\
\text { secret photo-taking of people was introduced. }\end{array}$ \\
\hline
\end{tabular}

${ }^{50}$ The source for the following table is Trial Transcript, supra note 4.

${ }^{51}$ Readers with long memories will recall the scene from the film Annie Hall (available at https://youtu.be/O7nPkpdFAic), where the lead characters, on a split screen, discuss their sex lives with their psychiatrists and display widely different interpretations of the same number.

${ }^{2}$ The prosecution seemed to miss the irony that for those disfavored by the government, China already is such a society. 
In the judgment, the court found the following elements to constitute the necessary serious circumstances: (a) the defendants wrote their investigative reports in order to make a profit; ${ }^{53}$ (b) the activity was carried on for a long time (four years); (c) the PIC involved covered a wide variety of types and was large in amount; ${ }^{54}$ and (d) the PIC acquired was unlawfully ${ }^{55}$ provided to clients inside and outside mainland China, with the result that the privacy and information security of citizens was directly infringed upon. ${ }^{56}$

When the circumstances of the Humphrey/Yu case are compared with the circumstances of Shanghai cases in the dataset, the virtually inescapable conclusion is that the sentences meted out to Humphrey and Yu are extreme outliers and do not reflect the usual judicial practice in Shanghai. The heaviest prison sentence for unlawful acquisition in Shanghai prior to the Humphrey/Yu case-in a set of over 90 cases and over 200 defendants - was 24 months. The maximum sentence under the Criminal Law is 36 months, and Humphrey was sentenced to 30 months (including the roughly one year spent in pre-trial detention). This sentence cannot be explained by the relatively paltry amount of PIC involved ( 256 items) or other circumstances mentioned in the trial transcript or the judgment.

This conclusion is reinforced by looking at cases involving private investigators in particular. As previously noted, Humphrey was sentenced to 30 months in prison. Prior to the Humphrey case, the longest prison sentence any private investigator in Shanghai had received was 12 months. Humphrey was found to have acquired about 250 pieces of PICmore than in most of the private investigator cases, but far less than in any of the Table 2 or Table 3 cases involving sentences of over 12 months. The Humphrey/Yu case appears to be the first one in which the defendant was investigating corporate misconduct, but it would seem odd for the court to deem this "serious circumstances." Certainly the court did not make anything of this fact in its judgment.

\footnotetext{
53 Neither the prosecution nor the court, in the trial transcript and the judgment, provide any figures for profits allegedly obtained by the defendants as a result of unlawful acquisition of PIC. The judgment stated that ChinaWhys had had gross revenues of approximately 21 million yuan from January 2009 to June 2013, see supra note 33 and accompanying text, but did not derive any profit figures from this or attribute specific profits to specific acts of unlawful acquisition of PIC. It is worth recalling here that the case was under investigation for over a year prior to the trial.

${ }^{54}$ As noted above, 256 items is in fact a trivially small amount of PIC in the universe of Shanghai cases.

55 Note that the defendants were not charged with unlawfully providing PIC; the judgment makes this assertion but does not really support it.

${ }^{56}$ The language here is virtually a direct quotation from the text of the judgment. See Trial Judgment, supra note 4, at 10.
} 
Table 4: Private investigator cases (arranged in ascending order of length of sentence)

\begin{tabular}{|c|c|c|c|c|c|c|}
\hline Case & Term & Fine & PIC & Nature & Means & $\begin{array}{l}\text { Serious circum- } \\
\text { stances }\end{array}$ \\
\hline Xue 2012 & 4 & 1,000 & 70 & $\begin{array}{l}\text { Residence, } \\
\text { vehicle info, } \\
\text { whereabouts, } \\
\text { infidelity }\end{array}$ & Purchased & $\begin{array}{l}\text { Private } \\
\text { investigator/debt } \\
\text { collection; 10,00o } \\
\text { profit }\end{array}$ \\
\hline Lu 2013b & 4 & 2,000 & 20 & $\begin{array}{l}\text { Residency, car, } \\
\text { bank, cell } \\
\text { location }\end{array}$ & Purchased & $\begin{array}{l}\text { Private } \\
\text { investigator/PIC } \\
\text { business; sold for } \\
\text { profit }\end{array}$ \\
\hline Liu 2013a & 6 & 10,000 & 32 & Residence; hotel & Purchased & $\begin{array}{l}\text { Private } \\
\text { investigator; } \\
38,700 \text { profit }\end{array}$ \\
\hline Peng 2012 & 6 & 2,000 & 16 & $\begin{array}{l}\text { Background } \\
\text { checks, } \\
\text { infidelity, child } \\
\text { behavior } \\
\text { monitoring, } \\
\text { business } \\
\text { intelligence }\end{array}$ & Purchased & Private investigator \\
\hline XXX 2012a & 6 & 2,000 & $\begin{array}{l}\text { Tar- } \\
\text { geted }\end{array}$ & $\begin{array}{l}\text { Phone records, } \\
\text { multimedia } \\
\text { messages, } \\
\text { WLAN records, } \\
\text { transaction fees, } \\
\text { financial, } \\
\text { vehicle } \\
\text { registration, } \\
\text { hotel records, } \\
\text { bank deposits }\end{array}$ & Purchased & $\begin{array}{l}\text { Private } \\
\text { investigator/illegal } \\
\text { PIC business;13,00o } \\
\text { profit }\end{array}$ \\
\hline Wu 2013 & 10 & 5,000 & 918 & $\begin{array}{l}\text { Information of } \\
\text { specific } \\
\text { individuals }\end{array}$ & $\begin{array}{l}\text { Purchased/ } \\
\text { investigation }\end{array}$ & $\begin{array}{l}\text { Private } \\
\text { investigator/PIC } \\
\text { business }\end{array}$ \\
\hline Lai $2010^{57}$ & 12 & 10,000 & 40 & $\begin{array}{l}\text { Individual } \\
\text { whereabouts, }\end{array}$ & Purchased & $\begin{array}{l}\text { Private } \\
\text { investigator; }\end{array}$ \\
\hline
\end{tabular}

${ }^{57}$ Lai purchased information from Zheng Xiangjun of the Shanghai Jinshan District Police Fire Brigade, paying 50 yuan for each piece of information on the whereabouts of a person and 1,00o yuan for a tip that someone had not yet checked out of a hotel. He paid Zheng a total of 270,00o yuan. More specifically, he purchased 40 items of PIC from Zheng on March 3, 2009 and made a profit of 40,000 yuan. 


\begin{tabular}{|c|c|c|c|c|c|c|}
\hline & & & & $\begin{array}{l}\text { debt collection, } \\
\text { infidelity }\end{array}$ & & $\begin{array}{l}\text { 40,ooo profit; paid } \\
\text { for on per-PIC } \\
\text { basis; target spec. } \\
\text { individuals; } \\
\text { purchased from } \\
\text { government } \\
\text { official }\end{array}$ \\
\hline XXX 2012b & 12 & 2,000 & 195 & $\begin{array}{l}\text { Locational info: } \\
\text { corporate } \\
\text { registration; } \\
\text { hotel } \\
\text { registration; car } \\
\text { registration; } \\
\text { flight } \\
\text { information; } \\
\text { etc. }\end{array}$ & $\begin{array}{l}\text { Purchased } \\
\text { from illegal } \\
\text { supplier }\end{array}$ & $\begin{array}{l}\text { Private } \\
\text { investigator/debt } \\
\text { collection }\end{array}$ \\
\hline Huo 2012 & 12 & 20,000 & 59 & $\begin{array}{l}\text { Phone records; } \\
\text { census data; } \\
\text { hotel } \\
\text { registration; } \\
\text { flight } \\
\text { information; } \\
\text { immigration } \\
\text { records; phone } \\
\text { location }\end{array}$ & Purchased & $\begin{array}{l}\text { Private } \\
\text { investigator/PIC } \\
\text { business }\end{array}$ \\
\hline Hua 2013 & 12 & 5,000 & 20 ind's. & $\begin{array}{l}\text { ID, financial, } \\
\text { real estate, bank } \\
\text { account \#, } \\
\text { vehicle } \\
\text { registration, etc. } \\
\text { of specific } \\
\text { individuals }\end{array}$ & Purchased & 50,900 profit \\
\hline
\end{tabular}

\section{Conclusion}

The Humphrey/Yu judgment is in many ways a disappointment. Even assuming for the sake of argument that Humphrey and Yu engaged in acts that the Chinese government has a legitimate interest in prohibiting, knew that they were doing so, and deserve to be punished, the case does little or nothing to inform others who wish to be compliant of what exactly constitutes the crime. The case does not analyze the concept of

\footnotetext{
${ }^{58}$ One of the individuals was Gao Qiang (高强), a Chinese politician who was Minister of Health from mid-2005 to mid-2007.
} 
PIC; it does not analyze the concept of "the aforesaid information" in Paragraph 4 of Article 253; it does not analyze what makes acquisition "unlawful"; it does not analyze the concept of "serious circumstances".

These problems, it should be noted, are not necessarily failings of the Humphrey/Yu judgment in particular; such vagueness pervades other judgments in unlawful acquisition cases. As a result, a legitimate industry - that of business intelligence-remains under a very threatening cloud. Indeed, any number of activities and businesses outside the realm of business intelligence are under a cloud as well, since a wide variety of activities involve the provision or collection of PIC as broadly defined, and the case offers no guidance as to when such provision or collection will be deemed illegal.

The case is even more troubling once we abandon the above assumptions. A comparison of the Humphrey/Yu case with all other cases in Shanghai provides very strong circumstantial evidence that their case was not simply an ordinary criminal case. Humphrey's sentence was by far the heaviest ever imposed in an unlawful acquisition case, and the sentences for both Humphrey and Yu were conspicuously heavy given the relatively small amount of PIC involved and the apparent absence of other serious circumstances. The sentences are also outliers when compared with those imposed on other private investigators. Even the court that tried Humphrey and Yu did not treat the case as an ordinary criminal case; although court judgments are supposed to be published on the court's web site in the absence of specific reasons not to (none of which, such as national security, were present in this case), the court never published the judgment and is apparently guarding it as a secret.

A final disturbing aspect of the case unrelated to the defendants is that one of the witnesses was a foreign lawyer resident in China and working at a Chinese law firm. According to the judgment, the lawyer testified-I presume reluctantly, but do not know - that a certain firm had hired ChinaWhys to investigate one or more employees. ${ }^{59}$ If the firm was a client of the Chinese law firm, this suggests that clients cannot expect strong confidentiality protections when dealing with Chinese law firms.

In short, the case offers little help to those who wish to comply with Chinese law other than to give up all information-gathering activities that might result in the receipt of information about individuals, and it offers little reassurance to those who suspect that the legal system can be used as a tool by those with sufficient influence and the will to wield it.

\footnotetext{
59 The lawyer, the law firm, and the firm that hired ChinaWhys are all named in the judgment, but as I am assuming until I learn otherwise that any lawyer and firm would have been forced to do the same, no purpose other than embarrassment of those concerned would be accomplished by naming them here.
} 


\section{APPENDIX A: TABLE OF CASES}

\begin{tabular}{|c|c|c|}
\hline $\begin{array}{l}\text { Abbreviated } \\
\text { Case Name }\end{array}$ & Full Citation & Chinese Case Number \\
\hline Beijing 2013 & $\begin{array}{l}\text { Beijing Moumou Dianzi Shangwu Youxian Gongsi Jaingsu Fengongsi deng } \\
\text { Feifa Huoqu Gongmin Geren Xinxi An (北京某某电子商务有限公司江苏分 } \\
\text { 公司等非法获取公民个人信息案) [In re Beijing Moumou }{ }^{1} \text { E-Commerce Co., } \\
\text { Ltd. Jiangsu Branch et al. Unlawful Obtainment of Personal Information of } \\
\text { Citizens] (Shanghai Pudong New Area People’s Ct. May 21, 2013), } \\
\text { http://www.pkulaw.cn/CLI.C.1422682. }\end{array}$ & (2013)浦刑初字第 871 号 \\
\hline Cao 2013 & $\begin{array}{l}\text { Cao Mou deng Feifa Huoqu Gongmin Geren Xinxi An (曹某等非法获取公民 } \\
\text { 个人信息案) [In re Cao Mou et al. Unlawful Obtainment of Personal } \\
\text { Information of Citizens] (Shanghai Songjian Dist. People's Ct. Jan. 7, 2013), } \\
\text { http://www.pkulaw.cn/CLI.C.1386937. }\end{array}$ & (2012)松刑初字第 1934 号 \\
\hline Chen 2o11a & $\begin{array}{l}\text { Chen Mou deng Feifa Huoqu Gongmin Geren Xinxi An (陈某等非法获取公 } \\
\text { 民个人信息、出售公民个人信案) [In re Chen Mou et al. Unlawful } \\
\text { Obtainment, Sale of Personal Information of Citizens, Unlawful } \\
\text { Obtainment of Personal Information of Citizens] (Shanghai Changning Dist. } \\
\text { People's Ct. Dec. 8, 2011), http://www.pkulaw.cn/CLI.C.961636. }\end{array}$ & (2011)长刑初字第 672 号 \\
\hline Chen 2011b & $\begin{array}{l}\text { Chen Mou deng Feifa Huoqu Gongmin Geren Xinxi An (陈某等非法获取公 } \\
\text { 民个人信息案) [In re Chen Mou et al. Unlawful Obtainment of Personal } \\
\text { Information of Citizens] (Shanghai Putou Dist. People’s Ct. Dec. 21, 2011), } \\
\text { http://www.pkulaw.cn/CLI.C.963164. }\end{array}$ & (2011)普刑初字第 791 号 \\
\hline Chen 2012 & $\begin{array}{l}\text { Chen Mou Feifa Huoqu Gongmin Geren Xinxi An (陈某非法获取公民个人信 } \\
\text { 息案) [In re Chen Mou Unlawful Obtainment of Personal Information of } \\
\text { Citizens] (Shanghai Huangpu Dist. People's Ct. Sept. 24, 2012), } \\
\text { http://www.pkulaw.cn/CLI.C.879412. }\end{array}$ & (2012)黄浦刑初字第 972 号 \\
\hline Chen 2013a & $\begin{array}{l}\text { Chen Moumou deng Zhapian, Feifa Huoqu Gongmin Geren Xinxi An (陈某 } \\
\text { 某等诈骗、非法获取公民个人信息案) [In re Chen Moumou et al. Fraud, } \\
\text { Unlawful Obtainment of Personal Information of Citizens] (Shanghai } \\
\text { Jinshan Dist. People’s Ct. Sept. 26, 2013), } \\
\text { http://www.pkulaw.cn/CLI.C.2280136. }\end{array}$ & (2013)金刑初字第 751 号 \\
\hline Chen 2013b & $\begin{array}{l}\text { Chen Mou Feifa Huoqu Gongmin Geren Xinxi An (陈某非法获取公民个人信 } \\
\text { 息案) [In re Chen Mou Unlawful Obtainment of Personal Information of } \\
\text { Citizens] (Shanghai Qingpu Dist. People’s Ct. Jan. 16, 2013), } \\
\text { http://www.pkulaw.cn/CLI.C.1386779. }\end{array}$ & (2013)青刑初字第 53 号 \\
\hline Chen 2014 & $\begin{array}{l}\text { Chen Moumou Feifa Huoqu Gongmin Geren Xinxi An (陈某某非法获取公民 } \\
\text { 个人信息案) [In re Chen Moumou Unlawful Obtainment of Personal } \\
\text { Information of Citizens] (Shanghai Songjiang Dist. People's Ct. Mar. 24, } \\
\text { 2014), http://www.pkulaw.cn/CLI.C.2609426. }\end{array}$ & (2014)松刑初字第 487 号 \\
\hline Deng 2014 & $\begin{array}{l}\text { Deng Mou deng Zhapian, Feifa Huoqu Gongmin Geren Xinxi An (邓某等诈 } \\
\text { 骗、非法获取公民个人信息案) [In re Deng Mou et al. Fraud, Unlawful } \\
\text { Obtainment of Personal Information of Citizens] (Shanghai Jinshan Dist. } \\
\text { People's Ct. June 25, 2014), http://www.pkulaw.cn/CLI.C.3041559 }\end{array}$ & (2014)金刑初字第 413 号 \\
\hline
\end{tabular}

1 "Mou" or "Moumou" in a case name means "a certain ...". It indicates that part of the name is being deliberately withheld. This is common in Chinese case reports. 


\begin{tabular}{|c|c|c|}
\hline Du 2014 & $\begin{array}{l}\text { Du Mou Feifa Huoqu Gongmin Geren Xinxi An (杜某非法获取公民个人信息 } \\
\text { 案) [In re Du Mou Unlawful Obtainment of Personal Information of } \\
\text { Citizens] (Shanghai Jinshan Dist. People’s Ct. Mar. 24, 2014), } \\
\text { http://www.pkulaw.cn/CLI.C.2609412. }\end{array}$ & (2014)金刑初字第 273 号 \\
\hline Fan 2014 & $\begin{array}{l}\text { Fan Moumou Feifa Huoqu Gongmin Geren Xinxi An (范某某非法获取公民 } \\
\text { 个人信息案) [In re Fan Moumou Unlawful Obtainment of Personal } \\
\text { Information of Citizens] (Shanghai Hongkou Dist. People’s Ct. Mar 24, } \\
\text { 2014), http://www.pkulaw.cn/CLI.C.2593331. }\end{array}$ & (2014)虹刑初字第 248 号 \\
\hline Fang 2013 & $\begin{array}{l}\text { Fang Mou Feifa Huoqu Gongmin Geren Xinxi An (方某非法获取公民个人信 } \\
\text { 息案) [In re Fang Mou Unlawful Obtainment of Personal Information of } \\
\text { Citizens] (Shanghai Zhabei Dist. People’s Ct. Nov. 1, 2013), } \\
\text { http://www.pkulaw.cn/CLI.C.2183194. }\end{array}$ & (2013)闸刑初字第 1199 号 \\
\hline Fu 2011 & $\begin{array}{l}\text { Fu Moumou Feifa Huoqu Gongmin Geren Xinxi An (付某某非法获取公民个 } \\
\text { 人信息案) [In re Fu Moumou Unlawful Obtainment of Personal Information } \\
\text { of Citizens] (Shanghai Qingpu Dist. People’s Ct. Mar. 15, 2013), } \\
\text { http://www.pkulaw.cn/CLI.C.2005008. }\end{array}$ & (2013) 青刑初字第 253 号 \\
\hline Fu 2014 & $\begin{array}{l}\text { Fu Jia deng Zhapain, Feifa Huoqu Gongmin Geren Xinxi An (符甲等许骗、 } \\
\text { 非法获取公民个人信息案) [In re Fu Jia et al. Fraud, Unlawful Obtainment of } \\
\text { Personal Information of Citizens] (Shanghai Pudong New Area People’s Ct. } \\
\text { July 31, 2014), http://www.pkulaw.cn/CLI.C.3194206. }\end{array}$ & (2014)浦刑初字第 2712 号 \\
\hline Gao 2013 & $\begin{array}{l}\text { Gao Mou Feifa Huoqu Gongmin Geren Xinxi An (高某非法获取公民个人信 } \\
\text { 息案) [In re Gao Mou Unlawful Obtainment of Personal Information of } \\
\text { Citizens] (Shanghai Changning Dist. People’s Ct. June 18, 2013), } \\
\text { http://www.pkulaw.cn/CLI.C.2057585. }\end{array}$ & (2013)长刑初字第 324 号 \\
\hline Gao 2014 & $\begin{array}{l}\text { Gao Liang Feifa Huoqu Gongmin Geren Xinxi An (高亮非法获取公民个人信 } \\
\text { 息案) [In re Gao Liang Unlawful Obtainment of Personal Information of } \\
\text { Citizens] (Shanghai Qingpu Dist. People’s Ct. Mar. 13, 2014), } \\
\text { http://www.pkulaw.cn/CLI.C.2566o68. }\end{array}$ & (2014)青刑初字第 310 号 \\
\hline $\begin{array}{l}\text { Guangzhou } \\
2013\end{array}$ & $\begin{array}{l}\text { Guangzhou Moumou Shangwu Fuwu Youxian Gongsi deng Feifa Huoqu } \\
\text { Gongmin Geren Xinxi An (广州某某商务服务有限公司等非法获取公民个人 } \\
\text { 信息案) [In re Guangzhou Moumou Business Services Ltd.] (Shanghai } \\
\text { Pudong New Area People’s Ct. Mar. 14, 2013), } \\
\text { http://www.pkulaw.cn/CLI.C.2007041. }\end{array}$ & (2013)浦刑初字第 442 号 \\
\hline Guo 2013 & $\begin{array}{l}\text { Guo Moumou Feifa Huoqu Gongmin Geren Xinxi An (郭某某非法获取公民 } \\
\text { 个人信息案) [In re Gu Moumou Unlawful Obtainment of Personal } \\
\text { Information of Citizens] (Shanghai Baoshan Dist. People's Ct. July 18, 2013), } \\
\text { http://www.pkulaw.cn/CLI.C.2058736. }\end{array}$ & (2013)宝刑初字第 1063 号 \\
\hline Han 2013 & $\begin{array}{l}\text { Han Mou Feifa Huoqu Gongmin Geren Xinxi An (韩某非法获取公民个人信 } \\
\text { 息案) [In re Han Mou Unlawful Obtainment of Personal Information of } \\
\text { Citizens] (Shanghai Zhabei Dist. People’s Ct. Nov. 4, 2013), } \\
\text { http://www.pkulaw.cn/CLI.C.218319o. }\end{array}$ & (2013)闸刑初字第 1188 号 \\
\hline Han 2014 & $\begin{array}{l}\text { Han Mou deng Feifa Tigong Gongmin Geren Xinxi, Feifa Huoqu Gongmin } \\
\text { Geren Xinxi An (韩某等非法提供公民个人信息、非法获取公民个人信息案) } \\
\text { [In re Han Mou et al. Unlawful Provision of Personal Information of } \\
\text { Citizens, Unlawful Obtainment of Personal Information of Citizens] } \\
\text { (Shanghai Xuhui Dist. People's Ct. Mar. 18, 2014), } \\
\text { http://www.pkulaw.cn/CLI.C.26o923o. }\end{array}$ & (2014)徐刑初字第 222 号 \\
\hline
\end{tabular}




\begin{tabular}{|c|c|c|}
\hline Hou 2011 & $\begin{array}{l}\text { Hou Qingbin Feifa Huoqu Gongmin Geren Xinxi An (侯庆斌非法获取公民 } \\
\text { 个人信息案) [In re Hou Qingbin Unlawful Obtainment of Personal } \\
\text { Information of Citizens] (Shanghai Pudong New Area People’s Ct. Aug. 18, } \\
\text { 2011), http://www.pkulaw.cn/CLI.C.1006635. }\end{array}$ & (2011)浦刑初字第 1877 号 \\
\hline Hua 2013 & $\begin{array}{l}\text { Hua Mou Feifa Huoqu Gongmin Geren Xinxi An (华某非法获取公民个人信 } \\
\text { 息案) [In re Hua Mou Unlawful Obtainment of Personal Information of } \\
\text { Citizens] (Shanghai Changning Dist. People’s Ct. Apr. 28, 2013), } \\
\text { http://www.pkulaw.cn/CLI.C.2053011. }\end{array}$ & (2013) 长刑初字第 170 号 \\
\hline Huang 2013 & $\begin{array}{l}\text { Huang Moumou deng Feifa Huoqu Gongmin Geren Xinxi An (黄某某等非法 } \\
\text { 获取公民个人信息案) [In re Huang Moumou et al. Unlawful Obtainment of } \\
\text { Personal Information of Citizens] (Shanghai Pudong New Area People’s Ct. } \\
\text { Mar. 13, 2013), http://www.pkulaw.cn/CLI.C.1385515. }\end{array}$ & (2013)浦刑初字第 682 号 \\
\hline Huang 2014 & $\begin{array}{l}\text { Huang Moumou Feifa Huoqu Gongmin Geren Xinxi An (黄某某非法获取公 } \\
\text { 民个人信息案) [In re Huang Moumou Unlawful Obtainment of Personal } \\
\text { Information of Citizens] (Shanghai Hongkou Dist. People’s Ct. Apr. 24, } \\
\text { 2014), http://www.pkulaw.cn/CLI.C.3075183. }\end{array}$ & (2014)虹刑初字第 251 号 \\
\hline Huo 2012 & $\begin{array}{l}\text { Huo Mou deng Feifa Huoqu Gongmin Geren Xinxi An（霍某等非法获取公 } \\
\text { 民个人信息案) [In re Huo Mou et al. Unlawful Obtainment of Personal } \\
\text { Information of Citizens] (Shanghai Pudong New Area People’s Ct. June 19, } \\
\text { 2012), http://www.pkulaw.cn/CLI.C.858513. }\end{array}$ & (2012)浦刑初字第 2092 号 \\
\hline Jiang 2014 & $\begin{array}{l}\text { Jiang Moujia deng Feifa Huoqu Gongmin Geren Xinxi An (姜某甲等非法获 } \\
\text { 取公民个人信息案) [In re Jiang Moujia et al Unlawful Obtainment of } \\
\text { Personal Information of Citizens] (Shanghai Qingpu Dist. People's Ct. Aug. } \\
\text { 21, 2014), http://www.pkulaw.cn/CLI.C.3285684. }\end{array}$ & (2014)青刑初字第 962 号 \\
\hline Keji 2013 & $\begin{array}{l}\text { Moumou Keji Youxian Gongsi deng Feifa Huoqu Gongmin Geren Xinxi An ( } \\
\text { 某某科技有限公司等非法获取公民个人信息案) [In re Moumou Technology } \\
\text { Co., Ltd. et al. Unlawful Obtainment of Personal Information of Citizens] } \\
\text { (Shanghai Pudong New Area People's Ct. Mar. 15, 2013), } \\
\text { http://www.pkulaw.cn/CLI.C.1384834. }\end{array}$ & (2013)浦刑初字第 683 号 \\
\hline Lai 2010 & $\begin{array}{l}\text { Lai XX Feifa Huoqu Gongmin Geren Xinxi An (赖 XX 非法获取公民个人信 } \\
\text { 息案) [In re Lai XX Unlawful Obtainment of Personal Information of } \\
\text { Citizens] (Shanghai Pudong New Area People’s Ct. Jan. 29, 2010), } \\
\text { http://www.pkulaw.cn/CLI.C. } 556657 \text {. }\end{array}$ & (2009)浦刑初字第 2728 号 \\
\hline Lan 2011 & $\begin{array}{l}\text { Lan xx deng Feifa Huoqu Gongmin Geren Xinxi An (兰×x等非法获取公民个 } \\
\text { 人信息案) [In re Lan xx et al. Unlawful Obtainment of Personal Information } \\
\text { of Citizens] (Shanghai Hongkou Dist. People's Ct. Jan. 21, 2011), } \\
\text { http://www.pkulaw.cn/CLI.C.1990065. }\end{array}$ & (2011)虹刑初字第 22 号 \\
\hline Li 2014a & $\begin{array}{l}\text { Li Mou Feifa Huoqu Gongmin Geren Xinxi An (李某非法获取公民个人信息 } \\
\text { 案) [In re Li Mou Unlawful Obtainment of Personal Information of Citizens] } \\
\text { (Shanghai Jinshan Dist. People's Ct. Mar. 18, 2014), } \\
\text { http://www.pkulaw.cn/CLI.C.2583308. }\end{array}$ & (2014)金刑初字第 249 号 \\
\hline $\mathrm{Li} 2014 \mathrm{~b}$ & $\begin{array}{l}\text { Li Moumou Feifa Huoqu Gongmin Geren Xinxi An (李某某非法获取公民个 } \\
\text { 人信息案) [In re Li Moumou Unlawful Obtainment of Personal Information } \\
\text { of Citizens] (Shanghai Minhang Dist. People’s Ct. Apr. 9, 2014), } \\
\text { http://www.pkulaw.cn/CLI.C.2679496. }\end{array}$ & (2014)闵刑初字第 846 号 \\
\hline Li 2013b & Li Moumou deng Feifa Huoqu Gongmin Geren Xinxi An (李某某等非法获取 & (2013)浦刑初字第 948 号 \\
\hline
\end{tabular}




\begin{tabular}{|c|c|c|}
\hline & $\begin{array}{l}\text { 公民个人信息案) [In re Li Moumou et al. Unlawful Obtainment of Personal } \\
\text { Information of Citizens] (Shanghai Pudong New Area People's Ct. Apr. 2, } \\
\text { 2013), http://www.pkulaw.cn/CLI.C.1339309. }\end{array}$ & \\
\hline Li $2013 \mathrm{C}$ & $\begin{array}{l}\text { Li Mou Feifa Huoqu Gongmin Geren Xinxi An (李某非法获取公民个人信息 } \\
\text { 案) [In re Li Mou Unlawful Obtainment of Personal Information of Citizens] } \\
\text { (Shanghai Songjian Dist. People's Ct. Dec. 9, 2013), } \\
\text { http://www.pkulaw.cn/CLI.C.2569832. }\end{array}$ & (2013)松刑初字第 1933 号 \\
\hline Li $2013 a$ & $\begin{array}{l}\text { Li Moumou Feifa Huoqu Gongmin Geren Xinxi An (李某某非法获取公民个 } \\
\text { 人信息案) [In re Li Moumou Unlawful Obtainment of Personal Information } \\
\text { of Citizens] (Shanghai Zhabei Dist. People’s Ct. Mar. 15, 2013), } \\
\text { http://www.pkulaw.cn/CLI.C.1383965. }\end{array}$ & (2013)闸刑初字第 201 号 \\
\hline Liang 2012 & $\begin{array}{l}\text { Liang Moumou Feifa Huoqu Gongmin Geren Xinxi An (梁某某非法获取公民 } \\
\text { 个人信息案) [In re Liang Moumou Unlawful Obtainment of Personal } \\
\text { Information of Citizens] (Shanghai Jinshan Dist. People’s Ct. Mar. 18, 2014), } \\
\text { http://www.pkulaw.cn/CLI.C.2583307. }\end{array}$ & (2014)金刑初字第 248 号 \\
\hline Liao 2014 & $\begin{array}{l}\text { Liao Moumou deng Feifa Huoqu Gongmin Geren Xinxi An (廖某某等非法获 } \\
\text { 取公民个人信息案) [In re Liao Moumou et al. Unlawful Obtainment of } \\
\text { Personal Information of Citizens] (Shanghai Xuhui Dist. People’s Ct. Apr. 2, } \\
\text { 2014), http://www.pkulaw.cn/CLI.C.2649486. }\end{array}$ & (2014)徐刑初字第 284 号 \\
\hline Liu 2013a & $\begin{array}{l}\text { Liu Mou Feifa Huoqu Gongmin Geren Xinxi An (刘某非法获取公民个人信 } \\
\text { 息案) [In re Lui Mou Unlawful Obtainment of Personal Information of } \\
\text { Citizens] (Shanghai Pudong New Area People's Ct. May 2, 2013), } \\
\text { http://www.pkulaw.cn/CLI.C.2002752. }\end{array}$ & (2013)浦刑初字第 1303 号 \\
\hline Liu 2014 & $\begin{array}{l}\text { Lui Mou deng Chushou Gongmin Geren Xinxi, Feifa Huoqu Gongmin Geren } \\
\text { Xinxi An (刘某等出售公民个人信息、非法获取公民个人信息案) [In re Lui } \\
\text { Mou et al. Sale of Personal Information of Citizens, Unlawful Obtainment of } \\
\text { Personal Information of Citizens] (Shanghai Huangpu Dist. People’s Ct. Apr. } \\
\text { 25, 2014), http://www.pkulaw.cn/CLI.C.3083486. }\end{array}$ & (2014)黄浦刑初字第 397 号 \\
\hline Liu $2013 b$ & $\begin{array}{l}\text { Liu Moumou Feifa Huoqu Gongmin Geren Xinxi An (刘某某非法获取公民个 } \\
\text { 人信息案) [In re Liu Moumou Unlawful Obtainment of Personal } \\
\text { Information of Citizens] (Shanghai Pudong New Area People’s Ct. Feb. 4, } \\
\text { 2013), http://www.pkulaw.cn/CLI.C.1337933. }\end{array}$ & (2013)浦刑初字第 443 号 \\
\hline Long 2014 & $\begin{array}{l}\text { Long Mou deng Feifa Huoqu Gongmin Geren Xinxi An (龙某等非法获取公 } \\
\text { 民个人信息案) [In re Long Mou et al. Unlawful Obtainment of Personal } \\
\text { Information of Citizens] (Shanghai Pudong New Area People's Ct. Feb. 13, } \\
\text { 2014), http://www.pkulaw.cn/CLI.C.2459454. }\end{array}$ & (2014)浦刑初字第 616 号 \\
\hline Lu 2010 & $\begin{array}{l}\text { Lu XX deng Feifa Huoqu Gongmin Geren Xinxi An (陆 XX 等非法获取公民 } \\
\text { 个人信息案) [In re Lu XX et al. Unlawful Obtainment of Personal } \\
\text { Information of Citizens] (Shanghai Pudong New Area People's Ct. Apr. 16, } \\
\text { 2010), http://www.pkulaw.cn/CLI.C.555500. }\end{array}$ & (2010)浦刑初字第 944 号 \\
\hline Lu 2013 & $\begin{array}{l}\text { Lu Mou Chushou, Feifa Tigong Gongmin Geren Xinxi, Feifa Huoqu } \\
\text { Gongmin Geren Xinxi An (卢某出售、非法提供公民个人信息、非法获取公 } \\
\text { 民个人信息案) [In re Lu Mou Sale, Unlawful Provision of Personal } \\
\text { Information of Citizens, Unlawful Obtainment of Personal Information of } \\
\text { Citizens] (Shanghai Hongkou Dist. People’s Ct. Dec. 19, 2013), } \\
\text { http://www.pkulaw.cn/CLI.C.2413750. }\end{array}$ & (2013)虹刑初字第 1370 号 \\
\hline Lu $2013 a$ & Lu Mou Chushou, Feifa Tigong Gongmin Geren Xinxi, Feifa Huoqu & (2013)虹刑初字第 1372 号 \\
\hline
\end{tabular}




\begin{tabular}{|c|c|c|}
\hline & $\begin{array}{l}\text { Gongmin Geren Xinxi An (陆某出售、非法提供公民个人信息、非法获取公 } \\
\text { 民个人信息案) [In re Lu Mou Sale, Unlawful Provision of Personal } \\
\text { Information of Citizens, Unlawful Obtainment of Personal Information of } \\
\text { Citizens] (Shanghai Hongkou Dist. People's Ct. Dec. 19, 2013), } \\
\text { http://www.pkulaw.cn/CLI.C.2277533. }\end{array}$ & \\
\hline Lu 2013b & $\begin{array}{l}\text { Lu Moumou Daoting Canjia Susong Feifa Huoqu Gongmin Geren Xinxi An ( } \\
\text { 陆某某到庭参加诉讼非法获取公民个人信息案) [In re Lu Moumou } \\
\text { Appearing in Court to Intervene Unlawful Obtainment of Personal } \\
\text { Information of Citizens] (Shanghai Jiading Dist. People’s Ct. Apr. 24, 2013), } \\
\text { http://www.pkulaw.cn/CLI.C.2052519. }\end{array}$ & (2013)嘉刑初字第 301 号 \\
\hline Lu 2014 & $\begin{array}{l}\text { Lu Moumou Feifa Huoqu Gongmin Geren Xinxi An (陆某某非法获取公民个 } \\
\text { 人信息案) [In re Lu Moumou Unlawful Obtainment of Personal Information } \\
\text { of Citizens] (Shanghai Changning Dist. People’s Ct. Mar. 18, 2014), } \\
\text { http://www.pkulaw.cn/CLI.C.2557225. }\end{array}$ & (2014)长刑初字第 171 号 \\
\hline Luo 2013 & $\begin{array}{l}\text { Luo Mou Chushou, Feifa Tigong Gongmin Geren Xinxi, Feifa Huoqu } \\
\text { Gongmin Geren Xinxi An (罗某出售、非法提供公民个人信息、非法获取公 } \\
\text { 民个人信息案) [In re Luo Mou Sale, Unlawful Provision of Personal } \\
\text { Information of Citizens, Unlawful Obtainment of Personal Information of } \\
\text { Citizens] (Shanghai Hongkou Dist. People's Ct. Dec. 23, 2013), } \\
\text { http://www.pkulaw.cn/CLI.C.2413751. }\end{array}$ & (2013)虹刑初字第 1371 号 \\
\hline Mu 2014 & $\begin{array}{l}\text { Mu Moumou deng Feifa Huoqu Gongmin Geren Xinxi An (穆某某等非法获 } \\
\text { 取公民个人信息案) [In re Mu Moumou et al Unlawful Obtainment of } \\
\text { Personal Information of Citizens] (Shanghai Qingpu Dist. People’s Ct. July } \\
\text { 24, 2014), http://www.pkulaw.cn/CLI.C.3194245. }\end{array}$ & (2014) 青刑初字第 847 号 \\
\hline Peng 2012 & $\begin{array}{l}\text { Peng Moumou Feifa Huoqu Gongmin Geren Xinxi An (彭某某非法获取公民 } \\
\text { 个人信息案) [In re Peng Moumou Unlawful Obtainment of Personal } \\
\text { Information of Citizens] (Shanghai Xuhui Dist. People’s Ct. Nov. 6, 2013), } \\
\text { http://www.pkulaw.cn/CLI.C.2168323. }\end{array}$ & (2013)徐刑初字第 922 号 \\
\hline Qian 2014 & $\begin{array}{l}\text { Qian Mou Feifa Huoqu Gongmin Geren Xinxi An (钱某非法提供公民个人信 } \\
\text { 息案) [In re Qian Mou Unlawful Obtainment of Personal Information of } \\
\text { Citizens] (Shanghai Jiading Dist. People’s Ct. Mar. 19, 2014), } \\
\text { http://www.pkulaw.cn/CLI.C.2804426. }\end{array}$ & (2014) 嘉刑初字第 274 号 \\
\hline Shao 2014 & $\begin{array}{l}\text { Shao Moumou Feifa Huoqu Gongmin Geren Xinxi An (邵某某非法获取公民 } \\
\text { 个人信息案) [In re Shao Moumou Unlawful Obtainment of Personal } \\
\text { Information of Citizens] (Shanghai Jinshan Dist. People's Ct. Jan. 23, 2014), } \\
\text { http://www.pkulaw.cn/CLI.C.2321857. }\end{array}$ & (2014)金刑初字第 86 号 \\
\hline Shanghai 2013b & $\begin{array}{l}\text { Shanghai Moumou Dianzi Shangwu Youxian Gongsi deng Feifa Huoqu } \\
\text { Gongmin Geren Xinxi An (上海某某电子商务有限公司等非法获取公民个人 } \\
\text { 信息、职务侵占案) [In re Shanghai Moumou E-Commerce Co., Ltd. et al. } \\
\text { Unlawful Obtainment of Personal Information of Citizens] (Shanghai } \\
\text { Pudong New Area People’s Ct. Aug. 2, 2013), } \\
\text { http://www.pkulaw.cn/CLI.C.2331039. }\end{array}$ & (2013)浦刑初字第 947 号 \\
\hline Shanghai 2013C & $\begin{array}{l}\text { Shanghai Moumou Xinxi Keji Youxian Gongsi deng Feifa Huoqu Gongmin } \\
\text { Geren Xinxi An (上海某某信息科技有限公司等非法获取公民个人信息案) } \\
\text { [In re Shanghai Moumou Information Technology Co., Ltd. et al. Unlawful } \\
\text { Obtainment of Personal Information of Citizens] (Shanghai Pudong New } \\
\text { Area People’s Ct. Mar. 21, 2013), http://www.pkulaw.cn/CLI.C.1384672. }\end{array}$ & (2013)浦刑初字第 864 号 \\
\hline
\end{tabular}




\begin{tabular}{|c|c|c|}
\hline Shanghai 2012 & $\begin{array}{l}\text { Shanghai Luo Moumou Moumou Yingxiao Fuwu Youxian Gongsi deng Feifa } \\
\text { Huoqu Gongmin Geren Xinxi An (上海罗某某某某营销服务有限公司等非法 } \\
\text { 获取公民个人信息案) [In re Shanghai Luo Moumou Moumou Marketing } \\
\text { Services Ltd. et al. Unlawful Obtainment of Personal Information of } \\
\text { Citizens] (Shanghai Zhabei Dist. People’s Ct. Dec. 28, 2012), } \\
\text { http://www.pkulaw.cn/CLI.C.1383953. }\end{array}$ & (2012)闸刑初字第 997 号 \\
\hline Shanghai 2013a & $\begin{array}{l}\text { Shanghai Moumou deng Feifa Huoqu Gongmin Geren Xinxi An (上海某某等 } \\
\text { 非法获取公民个人信息案) [In re Shanghai Moumou et al. Unlawful } \\
\text { Obtainment of Personal Information of Citizens] (Shanghai Changning Dist. } \\
\text { People’s Ct.) (Shanghai Changning Dist. People’s Ct. Dec. 24, 2013), } \\
\text { http://www.pkulaw.cn/CLI.C.2673522. }\end{array}$ & (2013)长刑初字第 862 号 \\
\hline Shanghai $2014 a$ & $\begin{array}{l}\text { Shanghai Moumou Touzi Guanli Youxian Gongsi deng Feifa Huoqu } \\
\text { Gongmin Geren Xinxi An (上海某某投资管理有限公司等非法获取公民个人 } \\
\text { 信息案) [In re Shanghai Moumou Investment Management Ltd. et al. } \\
\text { Unlawful Obtainment of Personal Information of Citizens] (Shanghai } \\
\text { Jinshan Dist. People’s Ct. Jan. 15, 2014), } \\
\text { http://www.pkulaw.cn/CLI.C.2288005. }\end{array}$ & (2014)金刑初字第 40 号 \\
\hline $\begin{array}{l}\text { Shanghai } \\
2014 \mathrm{~b}\end{array}$ & $\begin{array}{l}\text { Shanghai You Moumou Jianshen Guanli Youxian Gonsi deng Feifa Huoqu } \\
\text { Gongmin Geren Xinxi An (上海优某某健身管理有限公司等非法获取公民个 } \\
\text { 人信息案) [In re Shanghai You Moumou Fitness Management Co., Ltd. et al. } \\
\text { Unlawful Obtainment of Personal Information of Citizens] (Shanghai } \\
\text { Jinshan Dist. People’s Ct. Jan. 23, 2014), } \\
\text { http://www.pkulaw.cn/CLI.C.2321858. }\end{array}$ & (2014)金刑初字第 87 号 \\
\hline Shi 2014 & $\begin{array}{l}\text { Shi Moumou deng Feifa Huoqu Gongmin Geren Xinxi An (史某某等非法获 } \\
\text { 取公民个人信息案) [In re Shi Moumou et al. Unlawful Obtainment of } \\
\text { Personal Information of Citizens] (Shanghai Putou Dist. People's Ct. May 23, } \\
\text { 2014), http://www.pkulaw.cn/CLI.C.283196o. }\end{array}$ & (2014)普刑初字第 560 号 \\
\hline Song 2013 & $\begin{array}{l}\text { Song Mou Feifa Huoqu Gongmin Geren Xinxi An (宋某非法获取公民个人信 } \\
\text { 息案) [In re Song Mou Unlawful Obtainment of Personal Information of } \\
\text { Citizens] (Shanghai Qingpu Dist. People’s Ct. Jan. 22, 2013), } \\
\text { http://www.pkulaw.cn/CLI.C.1386816. }\end{array}$ & (2013)青刑初字第 98 号 \\
\hline Song 2014 & $\begin{array}{l}\text { Song Moumou Feifa Huoqu Gongmin Geren Xinxi An (宋某某非法获取公民 } \\
\text { 个人信息案) [In re Song Moumou Unlawful Obtainment of Personal } \\
\text { Information of Citizens] (Shanghai Xuhui Dist. People’s Ct. Feb. 27, 2014), } \\
\text { http://www.pkulaw.cn/CLI.C.2939486. }\end{array}$ & (2014)徐刑初字第 154 号 \\
\hline Tang 2014 & $\begin{array}{l}\text { Tang Moumou Feifa Huoqu Gongmin Geren Xinxi An (唐某某非法获取公民 } \\
\text { 个人信息案) [In re Tang Moumou Unlawful Obtainment of Personal } \\
\text { Information of Citizens] (Shanghai Hongkou Dist. People’s Ct. Jan 24, 2014), } \\
\text { http://www.pkulaw.cn/CLI.C.2286985. }\end{array}$ & (2013)虹刑初字第 1369 号 \\
\hline Tang 2014 & $\begin{array}{l}\text { Tang Moumou Feifa Huoqu Gongmin Geren Xinxi An (唐某某非法获取公民 } \\
\text { 个人信息案) [In re Tang Moumou Unlawful Obtainment of Personal } \\
\text { Information of Citizens] (Shanghai Hongkou Dist. People’s Ct. Mar. 25, } \\
\text { 2014), http://www.pkulaw.cn/CLI.C.2649539. }\end{array}$ & (2014)虹刑初字第 247 号 \\
\hline Tian 2014 & $\begin{array}{l}\text { Tian Moumou Feifa Huoqu Gongmin Geren Xinxi An (田某某非法获取公民 } \\
\text { 个人信息案) [In re Tian Moumou Unlawful Obtainment of Personal } \\
\text { Information of Citizens] (Shanghai Jinshan Dist. People’s Ct. Jan. 15, 2014), } \\
\text { http://www.pkulaw.cn/CLI.C.2288004. }\end{array}$ & (2014)金刑初字第 39 号 \\
\hline
\end{tabular}




\begin{tabular}{|c|c|c|}
\hline Wang 2013a & $\begin{array}{l}\text { Wang Moumou Feifa Huoqu Gongmin Geren Xinxi An (王某某非法获取公 } \\
\text { 民个人信息案) [In re Wang Moumou Unlawful Obtainment of Personal } \\
\text { Information of Citizens] (Shanghai Pudong New Area People's Ct. Mar. 15, } \\
\text { 2013), http://www.pkulaw.cn/CLI.C.1384832. }\end{array}$ & (2013)浦刑初字第 680 号 \\
\hline Wang 2013b & $\begin{array}{l}\text { Wang Moumou Feifa Huoqu Gongmin Geren Xinxi An (王某某非法获取公 } \\
\text { 民个人信息案) [In re Wang Moumou Unlawful Obtainment of Personal } \\
\text { Information of Citizens] (Shanghai Pudong New Area People’s Ct. Mar. 13, } \\
\text { 2013), http://www.pkulaw.cn/CLI.C.1385514. }\end{array}$ & (2013)浦刑初字第 679 号 \\
\hline Wang 2013C & $\begin{array}{l}\text { Wang A Feifa Huoqu Gongmin Geren Xinxi An (王 a 非法获取公民个人信息 } \\
\text { 案) [In re Wang A Unlawful Obtainment of Personal Information of } \\
\text { Citizens] (Shanghai Minhang Dist. People’s Ct. June 8, 2013), } \\
\text { http://www.pkulaw.cn/CLI.C.2009229. }\end{array}$ & (2013)闵刑初字第 776 号 \\
\hline Wang 2013d & $\begin{array}{l}\text { Wang xx Feifa Huoqu Gongmin Geren Xinxi An (王×x非法获取公民个人信 } \\
\text { 息案) [In re Wang xx Unlawful Obtainment of Personal Information of } \\
\text { Citizens] (Shanghai Hongkou Dist. People's Ct. May 10, 2013), } \\
\text { http://www.pkulaw.cn/CLI.C.1997272. }\end{array}$ & (2013)虹刑初字第 415 号 \\
\hline Wu 2012 & $\begin{array}{l}\text { Wu Mou Feifa Huoqu Gongmin Geren Xinxi An (武某非法获取公民个人信 } \\
\text { 息案) [In re Wu Mou Unlawful Obtainment of Personal Information of } \\
\text { Citizens] (Shanghai Putou Dist. People's Ct.) (Shanghai Putou Dist. People’s } \\
\text { Ct. Nov. 11, 2012), http://www.pkulaw.cn/CLI.C.1395357. }\end{array}$ & (2012)普刑初字第 869 号 \\
\hline Wu 2013 & $\begin{array}{l}\text { Wu Mou deng Feifa Huoqu Gongmin Geren Xinxi An (吴某等非法获取公民 } \\
\text { 个人信息案) [In re Wu Mou et al. Unlawful Obtainment of Personal } \\
\text { Information of Citizens] (Shanghai Zhabei Dist. People’s Ct. Oct. 18, 2013), } \\
\text { http://www.pkulaw.cn/CLI.C.21669o8. }\end{array}$ & (2013)闸刑初字第 1053 号 \\
\hline Xing 2014 & $\begin{array}{l}\text { Xing Moumou Feifa Huoqu Gongmin Geren Xinxi An (邢某某非法获取公民 } \\
\text { 个人信息案) [In re Xing Moumou Unlawful Obtainment of Personal } \\
\text { Information of Citizens] (Shanghai Hongkou Dist. People's Ct. Mar. 24, } \\
\text { 2014), http://www.pkulaw.cn/CLI.C.2804349. }\end{array}$ & (2014)虹刑初字第 246 号 \\
\hline Xu 2012 & $\begin{array}{l}\text { Xu x Feifa Huoqu Gongmin Geren Xinxi An (徐×非法获取公民个人信息案) } \\
\text { [In re Xu X Unlawful Obtainment of Personal Information of Citizens] } \\
\text { (Shanghai Hongkou Dist. People's Ct. Aug. 15, 2012), } \\
\text { http://www.pkulaw.cn/CLI.C.1395825. }\end{array}$ & (2012)虹刑初字第 797 号 \\
\hline $\mathrm{Xu} 2013 \mathrm{a}$ & $\begin{array}{l}\text { Xu Mou Feifa Huoqu Gongmin Geren Xinxi An (徐某非法获取公民个人信息 } \\
\text { 案) [In re Xu Mou Unlawful Obtainment of Personal Information of } \\
\text { Citizens] (Shanghai Pudong New Area People's Ct. Apr. 18, 2013), } \\
\text { http://www.pkulaw.cn/CLI.C.1346668. }\end{array}$ & (2013)浦刑初字第 1087 号 \\
\hline $\mathrm{Xu} 2013 \mathrm{~b}$ & $\begin{array}{l}\text { Xu Moumou Feifa Huoqu Gongmin Geren Xinxi An (徐某某非法获取公民个 } \\
\text { 人信息案) [In re Xu Moumou Unlawful Obtainment of Personal } \\
\text { Information of Citizens] (Shanghai Pudong New Area People’s Ct. Feb. 4, } \\
\text { 2013), http://www.pkulaw.cn/CLI.C.1385502. }\end{array}$ & (2013)浦刑初字第 441 号 \\
\hline Xue 2012 & $\begin{array}{l}\text { Xue Mou Feifa Huoqu Gongmin Geren Xinxi An (薛某非法获取公民个人信 } \\
\text { 息案) [In re Xue Mou Unlawful Obtainment of Personal Information of } \\
\text { Citizens] (Shanghai Songjian Dist. People’s Ct. July 26, 2012), } \\
\text { http://www.pkulaw.cn/CLI.C.953035. }\end{array}$ & (2012)松刑初字第 1050 号 \\
\hline XXX 2012a & $\begin{array}{l}\text { XXX Feifa Huoqu Gongmin Geren Xinxi An (XXX 非法获取公民个人信息案) } \\
\text { [In re XXX Unlawful Obtainment of Personal Information of Citizens] }\end{array}$ & (2012)徐刑初字第 713 号 \\
\hline
\end{tabular}




\begin{tabular}{|c|c|c|}
\hline & $\begin{array}{l}\text { (Shanghai Xuhui Dist. People's Ct. Sept. 17, 2012), } \\
\text { http://www.pkulaw.cn/CLI.C.1399252. }\end{array}$ & \\
\hline $\mathrm{XXX} 2012 \mathrm{~b}$ & $\begin{array}{l}\text { XXX Feifa Huoqu Gongmin Geren Xinxi An (XXX 非法获取公民个人信息案) } \\
\text { [In re XXX Unlawful Obtainment of Personal Information of Citizens] } \\
\text { (Shanghai Xuhui Dist. People's Ct. Sept. 7, 2012), } \\
\text { http://www.pkulaw.cn/CLI.C.951951. }\end{array}$ & (2012)徐刑初字第 680 号 \\
\hline Yan 2012 & $\begin{array}{l}\text { Yan Mou Feifa Huoqu Gongmin Geren Xinxi An (颜某非法获取公民个人信 } \\
\text { 息案) [In re Yan Mou Unlawful Obtainment of Personal Information of } \\
\text { Citizens] (Shanghai Huangpu Dist. People's Ct. Sept. 9, 2012), } \\
\text { http://www.pkulaw.cn/CLI.C.879410. }\end{array}$ & (2012)黄浦刑初字第 971 号 \\
\hline Yang 2014 & $\begin{array}{l}\text { Yang Mou deng Feifa Tigong Gongmin Geren Xinxi, Feifa Huoqu Gongmin } \\
\text { Geren Xinxi An (杨某等非法提供公民个人信息、非法获取公民个人信息案) } \\
\text { [In re Yang Mou et al. Unlawful Provivion of Personal Information of } \\
\text { Citizens, Unlawful Obtainment of Personal Information of Citizens] } \\
\text { (Shanghai Zhabei Dist. People's Ct. Apr. 24, 2014), } \\
\text { http://www.pkulaw.cn/CLI.C.2810328. }\end{array}$ & (2014)闸刑初字第 244 号 \\
\hline Yao 2013 & $\begin{array}{l}\text { Yao Moumou Chushou, Feifa Tigong Gongmin Geren Xinxi, Feifa Huoqu } \\
\text { Gongmin Geren Xinxi An (姚某某出售、非法提供公民个人信息、非法获取 } \\
\text { 公民个人信息案) [In re Yao Moumou Sale, Unlawful Provision of Personal } \\
\text { Information of Citizens, Unlawful Obtainment of Personal Information of } \\
\text { Citizens] (Shanghai Hongkou Dist. People’s Ct. Dec. 19, 2013), } \\
\text { http://www.pkulaw.cn/CLI.C.2277534. }\end{array}$ & (2013)虹刑初字第 1373 号 \\
\hline Ye 2013 & $\begin{array}{l}\text { Ye Mou deng Feifa Huoqu Gongmin Geren Xinxi An 叶某等非法获取公民个 } \\
\text { 人信息案) [In re Ye Mou et al. Unlawful Obtainment of Personal } \\
\text { Information of Citizens] (Shanghai Fengxian Dist. People’s Ct. July 30, 2013), } \\
\text { http://www.pkulaw.cn/CLI.C.1976859. }\end{array}$ & (2013)奉刑初字第 649 号 \\
\hline Zhang 2014a & $\begin{array}{l}\text { Zhang Moumou Feifa Huoqu Gongmin Geren Xinxi An (张某某非法获取公 } \\
\text { 民个人信息案) [In re Zhang Moumou Unlawful Obtainment of Personal } \\
\text { Information of Citizens] (Shanghai Hongkou Dist. People’s Ct. Apr. 4, 2014), } \\
\text { http://www.pkulaw.cn/CLI.C.2649539. }\end{array}$ & (2014)虹刑初字第 250 号 \\
\hline Zhang 2014b & $\begin{array}{l}\text { Zhang Moumou Feifa Huoqu Gongmin Geren Xinxi An (张某某非法获取公 } \\
\text { 民个人信息案) [In re Zhang Moumou Unlawful Obtainment of Personal } \\
\text { Information of Citizens] (Shanghai Jinshan Dist. People's Ct. Jan. 22, 2014), } \\
\text { http://www.pkulaw.cn/CLI.C.2288oog. }\end{array}$ & (2014)金刑初字第 68 号 \\
\hline Zhang 2014c & $\begin{array}{l}\text { Zhang Moumou Feifa Huoqu Gongmin Geren Xinxi An (张某某非法获取公 } \\
\text { 民个人信息案) [In re Zhang Moumou Unlawful Obtainment of Personal } \\
\text { Information of Citizens] (Shanghai Xuhui Dist. People’s Ct. July 23, 2014), } \\
\text { http://www.pkulaw.cn/CLI.C.3208240. }\end{array}$ & (2014)徐刑初字第 672 号 \\
\hline Zhang 2013 & $\begin{array}{l}\text { Zhang Mou Feifa Huoqu Gongmin Geren Xinxi An (张某非法获取公民个人 } \\
\text { 信息案) [In re Zhang Mou Unlawful Obtainment of Personal Information of } \\
\text { Citizens] (Shanghai Pudong New Area People's Ct. Mar. 15, 2013), } \\
\text { http://www.pkulaw.cn/CLI.C.1338202. }\end{array}$ & (2013)浦刑初字第 681 号 \\
\hline Zhang 2014d & $\begin{array}{l}\text { Zhang Moumou deng Feifa Huoqu Gongmin Geren Xinxi An (章某某等非法 } \\
\text { 获取公民个人信息案) [In re Zhang Moumou et al. Unlawful Obtainment of } \\
\text { Personal Information of Citizens] (Shanghai Pudong New Area People’s Ct. } \\
\text { Feb. 24, 2014), http://www.pkulaw.cn/CLI.C.2321788. }\end{array}$ & (2014)浦刑初字第 571 号 \\
\hline Zhang 2014e & Zhang Yi Feifa Huoqu Gongmin Geren Xinxi, Chushou Gongmin Geren & (2013)虹刑初字第 1368 号 \\
\hline
\end{tabular}




\begin{tabular}{|c|c|c|}
\hline & $\begin{array}{l}\text { Xinxi An (张乙非法获取公民个人信息、出售公民个人信息案) [In re Zhang } \\
\text { Yi Unlawful Obtainment of Personal Information of Citizens] (Shanghai } \\
\text { Hongkou Dist. People's Ct. Jan. 24, 2014), } \\
\text { http://www.pkulaw.cn/CLI.C.2286984. }\end{array}$ & \\
\hline Zhao 2014 & $\begin{array}{l}\text { Zhao Moumou Feifa Huoqu Gongmin Geren Xinxi An (赵某某非法获取公民 } \\
\text { 个人信息案) [In re Zhao Moumou Unlawful Obtainment of Personal } \\
\text { Information of Citizens] (Shanghai Xuhui Dist. People’s Ct. Aug. 29, 2014), } \\
\text { http://www.pkulaw.cn/CLI.C.3431761. }\end{array}$ & (2014)徐刑初字第 851 号 \\
\hline Zhou 2010 & $\begin{array}{l}\text { Zhou Mou deng Feifa Huoqu Gongmin Geren Xinxi An（周某等非法获取公 } \\
\text { 民个人信息案) [In re Zhou mou et al. Unlawful Obtainment of Personal } \\
\text { Information of Citizens] (Shanghai Pudong New Area People’s Ct. Aug. 5, } \\
\text { 2010), http://www.pkulaw.cn/CLI.C.6oog64. }\end{array}$ & (2010)浦刑初字第 1450 号 \\
\hline Zhou 2014a & $\begin{array}{l}\text { Zhou Moumou deng Feifa Huoqu Gongmin Geren Xinxi An (周某某等非法 } \\
\text { 获取公民个人信息案) [In re Zhang Moumou et al. Unlawful Obtainment of } \\
\text { Personal Information of Citizens] (Shanghai Pudong New Area People's Ct. } \\
\text { Feb. 20, 2014), http://www.pkulaw.cn/CLI.C.2487648. }\end{array}$ & (2014)浦刑初字第 663 号 \\
\hline Zhou 2014b & $\begin{array}{l}\text { Zhang Yi Feifa Huoqu Gongmin Geren Xinxi An (周乙非法获取公民个人信 } \\
\text { 息案) [In re Zhou Yi Unlawful Obtainment of Personal Information of } \\
\text { Citizens] (Shanghai Hongkou Dist. People’s Ct. Mar 25, 2013), } \\
\text { http://www.pkulaw.cn/CLI.C.2585918. }\end{array}$ & (2014)虹刑初字第 249 号 \\
\hline Zhu 2012b & $\begin{array}{l}\text { Zhu Moumou deng Feifa Huoqu Gongmin Geren Xinxi An (朱某某等非法获 } \\
\text { 取公民个人信息案) [In re Zhu Moumou et al. Unlawful Obtainment of } \\
\text { Personal Information of Citizens] (Shanghai Qingpu Dist. People’s Ct. Apr. } \\
\text { 17, 2014), http://www.pkulaw.cn/CLI.C.2683405. }\end{array}$ & (2014)青刑初字第 440 号 \\
\hline Zhu 2012a & $\begin{array}{l}\text { Zhu Moumou deng Xinyongka Zhapian, Fanghai Xinyongka Guanli, Yanshi, } \\
\text { Yinman Fanzui Suode, Chushou Gongmin Geren Xinxi, Feifa Huoqu } \\
\text { Gongmin Geren Xinxi An (朱某某等信用卡诈骗、妨害信用卡管理、掩饰、 } \\
\text { 隐瞒犯罪所得、出售公民个人信息、非法获取公民个人信息案) [In re Zhu } \\
\text { Moumou et al. Credit Card Fraud, Hinderance of Credit Card Management, } \\
\text { Concealing Criminal Gains, Sale of Personal Information of Citizens, } \\
\text { Unlawful Obtainment of Personal Information of Citizens] (Shanghai } \\
\text { Zhabei Dist. People's Ct. May 18, 2012), } \\
\text { http://www.pkulaw.cn/CLI.C.1385459. }\end{array}$ & (2011)闸刑初字第 823 号 \\
\hline Zuo 2013 & $\begin{array}{l}\text { Zuo Mou Feifa Huoqu Gongmin Geren Xinxi An (左某非法获取公民个人信 } \\
\text { 息案) [In re Zuo Mou Unlawful Obtainment of Personal Information of } \\
\text { Citizens] (Shanghai Pudong New Area People’s Ct. Mar. 21, 2013), } \\
\text { http://www.pkulaw.cn/CLI.C.1338232. }\end{array}$ & (2013)浦刑初字第 865 号 \\
\hline
\end{tabular}




\section{APPENDIX B: CASE DATA}

The following is a compilation of all the data used in this research. The cases are arranged by date, beginning with the earliest. The amount of PIC, the nature of the PIC, and the means of acquisition are also listed. In the rightmost column, "Serious Circumstances," certain aspects of the case that could be construed as serious circumstances or relevant for sentencing are listed. The term "EXEMPT" means that the defendant was found guilty of unlawful acquisition but for other reasons was exempted from punishment. In the Zhou 2010 case, a number of defendants were found guilty but their sentences were not mentioned. Here the table will show a question mark. For certain cases, such as $X u 2013 b$, the court filtered the PIC for duplicates. Where this is the case, the PIC amount will have the initial number and following it the number excluding duplicates in parentheses. The full citation for the cases is found in Appendix A.

\begin{tabular}{|c|c|c|c|c|c|c|c|c|}
\hline Name & Date & Def. & Term & Fine & PIC Amount & Nature of PIC & Means & Serious Circumstances \\
\hline Lai 2010 & 2010.01 .29 & 赖 XX & 12 & 10,000 & 40 & Individual whereabouts. & Purch. & $\begin{array}{l}\text { Private investigator; } 40, \text { ooo yuan profit; paid for on } \\
\text { per PIC basis; target spec individuals. }\end{array}$ \\
\hline \multirow[t]{2}{*}{ Lu 2010} & \multirow[t]{2}{*}{2010.04 .16} & 赵 XX & 10 & 10,000 & 200,000 & Unclear. & Purch. & 2, ooo yuan profit. \\
\hline & & 陆 XX & 11 & 10,000 & 140,000 & Unclear. & Purch. & 1,500 yuan profit. \\
\hline \multirow[t]{10}{*}{ Zhou 2010} & \multirow[t]{10}{*}{2010.08 .05} & 周某 & 12 & 20,000 & 980,000 & \multirow[t]{10}{*}{ Info on wealthy individuals. } & Acq. & Principal; sold for profit. \\
\hline & & 李某某 & 24 & 40,000 & $30,000,000$ & & Acq. & Principal. \\
\hline & & 张某某 & $?$ & $?$ & $10,000,000$ & & Acq. & Accessory. \\
\hline & & 张某 & $?$ & $?$ & 980,000 & & Acq. & Accessory. \\
\hline & & 胡某某 & $?$ & $?$ & 980,000 & & Acq. & Accessory. \\
\hline & & 李某某 & $?$ & $?$ & 980,000 & & Acq. & Accessory. \\
\hline & & 王某某 & $?$ & $?$ & 980,000 & & Acq. & Accessory. \\
\hline & & 张某 & $?$ & $?$ & $30,980,000$ & & Acq. & Accessory. \\
\hline & & 陈某某 & $?$ & $?$ & 240,000 & & Trick. & Accessory; fraud. \\
\hline & & 余某某 & EXEMPT & EXEMPT & $20,000,000$ & & Purch./trick. & Accessory. \\
\hline \multirow[t]{10}{*}{ Lan 2011} & \multirow[t]{10}{*}{2011.01 .21} & 李 $x$ & 3 & $1, \mathrm{OOO}$ & 207,898 & Info on elementary school children. & Purch./trade. & Accessory; sold for profit. \\
\hline & & 叶 $x x$ & 10 & 5,000 & $2,540,844$ & Info on elementary school children. & Purch./trade. & Principal; sold for profit; paid 3,ooo for PIC. \\
\hline & & 兰 $x x$ & 18 & 15,000 & $16,823,533$ & Purchase orders. & Purch./trade. & For profit; paid 3,40o for PIC. \\
\hline & & 曹 $x x$ & EXEMPT & EXEMPT & 41,042 & Purchase orders. & Purch./trade. & Accessory; sold for profit; paid 1,ooo for PIC. \\
\hline & & 费 $x x$ & 11 & 7,000 & $2,767,846$ & Students and business owners. & Purch./trade. & For profit. \\
\hline & & 麻 $x x$ & 11 & 5,000 & $2,767,846$ & Students and business owners. & Purch./trade. & For profit. \\
\hline & & 杨 $x x$ & 17 & 15,000 & $16,823,533$ & Unclear. & Purch./trade. & For profit. \\
\hline & & 孟 $x x$ & 10.5 & 10,000 & $6,246,842$ & Unclear. & Purch./trade. & 3,400 profit; paid 1,00o for PIC. \\
\hline & & 向 $x x$ & EXEMPT & EXEMPT & 30,449 & Unclear. & Purch./trade. & Accessory; sold for profit; paid 2,ooo for PIC. \\
\hline & & 刘 $x x$ & NONE & 3,000 & 42,191 & Unclear. & Purch./trade. & For profit. \\
\hline
\end{tabular}


Draft date: Aug. 5, 2015

\begin{tabular}{|c|c|c|c|c|c|c|c|c|}
\hline & & 卓x & 5 & 2,000 & 336,187 & Unclear. & Purch./trade. & Accessory; sold for profit. \\
\hline & & 谷 $x x$ & 8 & 5,000 & 755,599 & Unclear. & Purch./trade. & For profit; paid 1,50o for PIC. \\
\hline & & 周 $x \times$ & 14 & 10,000 & $6,246,842$ & Unclear. & Purch./trade. & For profit; paid 3,400 for PIC. \\
\hline Hou 2011 & 2011.08 .18 & 侯庆斌 & NONE & 5,000 & 550 & Finance. & Trade. & \\
\hline \multirow[t]{2}{*}{ Chen $2011 \mathrm{a}$} & \multirow[t]{2}{*}{2011.12 .08} & 陈某 & 7 & 2,000 & 88 & Phone records. & Purch. & $\begin{array}{l}\text { 20,ooo profit; paid 17,00o for PIC; source telecomm } \\
\text { co. }\end{array}$ \\
\hline & & 陆某 & NONE & 5,000 & 10 & Phone records. & Purch. & 900 profit; paid 4,10o for PIC; source telecomm co. \\
\hline \multirow[t]{6}{*}{ Chen 2011b } & \multirow[t]{6}{*}{2011.12 .21} & 张某 & 4 & 4,000 & \multirow[t]{6}{*}{ Unclear. } & \multirow[t]{6}{*}{ Real estate. } & \multirow[t]{6}{*}{ Acq. } & \multirow[t]{6}{*}{ None. } \\
\hline & & 辛某 & 4 & 4,000 & & & & \\
\hline & & 陈某 & 10 & 10,000 & & & & \\
\hline & & 阳某 & 10 & 10,000 & & & & \\
\hline & & 赵某 & 12 & 12,000 & & & & \\
\hline & & 刘某 & 8.5 & 8,000 & & & & \\
\hline \multirow[t]{6}{*}{ Zhu 2012a } & \multirow[t]{6}{*}{2012.05 .18} & 章某某 & 3 & 5,000 & 50 & \multirow[t]{6}{*}{ Finance. } & \multirow[t]{6}{*}{ Purch. } & 300 yuan profit; paid 10-10o for PIC. \\
\hline & & 林某 & 4 & 10,000 & 100 & & & 1,ooo yuan profit; paid 10-100 for PIC. \\
\hline & & 王某某 & 6 & 10,000 & 250 & & & 4,ooo yuan profit; paid 10-10o for PIC. \\
\hline & & 陈某某 & 6 & 10,000 & 300 & & & Thousands of yuan of profit; paid 10-100 for PIC. \\
\hline & & 任某某 & 15 & 30,000 & 1,000 & & & 30,ooo yuan profit; paid 10-100 for PIC. \\
\hline & & 颜某某 & 15 & 30,000 & 2,000 & & & 20,ooo yuan profit; paid 10-10o for PIC. \\
\hline \multirow[t]{2}{*}{ Huo 2012} & \multirow[t]{2}{*}{2012.06 .19} & 霍某 & 12 & 20,000 & 59 & \multirow{2}{*}{$\begin{array}{l}\text { Phone records; census data; hotel } \\
\text { registration; flight information; } \\
\text { immigration records; phone location. }\end{array}$} & \multirow[t]{2}{*}{ Purch. } & Private investigator/PIC business. \\
\hline & & 沙某某 & 6 & 5,000 & 9 & & & Private investigator/accessory; PIC business; \\
\hline Xue 2012 & 2012.07 .26 & 薛某 & 4 & 1,000 & 70 & Residence and vehicle info. & Purch. & $\begin{array}{l}\text { Private investigator/debt collection; 10,000 yuan } \\
\text { profit. }\end{array}$ \\
\hline Xu 2012 & 2012.08 .15 & 徐x & 5 & 2,000 & unclear & Contact. & Acq. & For profit. \\
\hline XXX 2012b & 2012.09 .07 & $\mathrm{XXX}$ & 12 & 2,000 & 195 & $\begin{array}{l}\text { Locational info: corporate } \\
\text { registration; hotel registration; car } \\
\text { registration; flight information; etc. }\end{array}$ & $\begin{array}{l}\text { Purch. from } \\
\text { illegal supplier. }\end{array}$ & Private investigator/debt collection. \\
\hline XXX 2012a & 2012.09 .17 & $\mathrm{XXX}$ & 6 & 2,000 & Targeted & $\begin{array}{l}\text { Phone records, multimedia } \\
\text { messages, WLAN recrods, } \\
\text { transaction fees, finaicial, vehicle } \\
\text { registration, hotel records, bank } \\
\text { deposits }\end{array}$ & Purch. & $\begin{array}{l}\text { Private investigator/illegal PIC business;13,00o } \\
\text { profit. }\end{array}$ \\
\hline Chen 2012 & 2012.09 .24 & 陈某 & 6 & 1,000 & 28 & Unclear. & Purch. & Sold for profit. \\
\hline Yan 2012 & 2012.09 .24 & 颜某 & 6 & 1,000 & 100 & Unclear. & Purch. & Sold for profit. \\
\hline Wu 2012 & 2012.11 .02 & 武某 & 7 & 10,000 & 337 & Financial, hotel, residence. & Purch. & For profit. \\
\hline \multirow[t]{4}{*}{ Shanghai 2012} & \multirow[t]{4}{*}{2012.12 .28} & 王某 & 12 & 5,000 & \multirow[t]{4}{*}{ 90,000,000 } & \multirow{4}{*}{$\begin{array}{l}\text { Contact; bank; infant; consumer } \\
\text { records. }\end{array}$} & \multirow[t]{4}{*}{ Purch. } & \multirow{4}{*}{$\begin{array}{l}\text { For profit; the company paid } 2,500,000 \text { for PIC; the } \\
\text { rest of the defendants took part in acquiring the } \\
\text { PIC. }\end{array}$} \\
\hline & & 孙某某 & 12 & 10,000 & & & & \\
\hline & & 李某 & 18 & 20,000 & & & & \\
\hline & & 崔某某 & 24 & 20,000 & & & & \\
\hline
\end{tabular}


Draft date: Aug. 5, 2015

\begin{tabular}{|c|c|c|c|c|c|c|c|c|}
\hline & & $\begin{array}{l}\text { 上海罗某某某 } \\
\text { 某营销服务有 } \\
\text { 限公司 }\end{array}$ & N/A & $1,000,000$ & & & & \\
\hline \multirow[t]{7}{*}{ Cao 2013} & \multirow[t]{7}{*}{2013.01 .07} & 叶某 & 5 & 1,000 & 200 & \multirow{7}{*}{$\begin{array}{l}\text { The opinion referred to “40o data" } \\
\text { ( } 400 \text { 数据信息), although it is } \\
\text { unclear what this is. }\end{array}$} & Acq. & Profit unknown. \\
\hline & & 沙某 & 5 & 1,000 & 2 & & Purch. & Hundreds of yuan of profit; paid hundreds for PIC. \\
\hline & & 万某 & 6 & 1,000 & 200 & & Acq. & Tens of thousands of yuan of profit. \\
\hline & & 曾某 & 6 & 1,000 & 6 & & Purch. & Thousands of yuan of profit; paid thousands for PIC. \\
\hline & & 杨某 & 6 & 1,000 & 8 & & Purch. & Thousands of yuan of profit; paid thousands for PIC. \\
\hline & & 曹某 & 8 & 1,000 & 200 & & Acq. & Tens of thousands of yuan profit. \\
\hline & & 杨某 & 8 & 1,000 & 200 & & Purch. & $\begin{array}{l}\text { Tens of thousands of yuan profit; paid tens of } \\
\text { thousands for PIC. }\end{array}$ \\
\hline Chen 2013b & 2013.01 .16 & 陈某 & 6 & 10,000 & 20,000 & Unclear. & Acq. & Criminal sale; \\
\hline Song 2013 & 2013.01 .22 & 宋某 & 9 & 10,000 & 50,000 & Contact. & Acq. & Criminal sale. \\
\hline $\mathrm{Xu} 2013 \mathrm{~b}$ & 2013.02 .04 & 徐某某 & 6 & 10,000 & $\begin{array}{l}1, \mathrm{OOO}, \mathrm{OOOO} \\
(280,000)\end{array}$ & Purchase orders. & Purch. & Paid 400 for PIC. \\
\hline Liu $2013 b$ & 2013.02 .04 & 刘某某 & 8 & 15,000 & $\begin{array}{l}1,000,000 \\
(280,000)\end{array}$ & Purchase orders. & Purch. & Paid 10,000 for PIC. \\
\hline Huang 2013 & 2013.03 .13 & 黄某某 & 6 & 10,000 & $\begin{array}{l}1,000,000 \\
(280,000)\end{array}$ & Purchase orders. & Purch. & Paid 100 for PIC. \\
\hline Wang 2013b & 2013.03 .13 & 王某某 & 7 & 10,000 & $\begin{array}{l}1,000,000 \\
(280,000)\end{array}$ & Purchase orders. & Trade. & Sold for 119 profit. \\
\hline \multirow{4}{*}{$\begin{array}{l}\text { Guangzhou } \\
2013\end{array}$} & \multirow[t]{4}{*}{2013.03 .14} & 江某某 & 6 & 10,000 & \multirow{4}{*}{$\begin{array}{l}1,000,000 \\
(280,000)\end{array}$} & \multirow[t]{4}{*}{ Unclear. } & \multirow[t]{4}{*}{ Purch. } & \multirow{4}{*}{$\begin{array}{l}\text { The company paid 5,ooo for PIC, and it was } \\
\text { presumably for a profit. }\end{array}$} \\
\hline & & 张某某 & 6 & 10,000 & & & & \\
\hline & & $\begin{array}{l}\text { 广州某某商务 } \\
\text { 服务有限公司 }\end{array}$ & $\mathrm{N} / \mathrm{A}$ & 30,000 & & & & \\
\hline & & 孙某某 & NONE & 30,000 & & & & \\
\hline Fu 2011 & 2013.03 .15 & 付某某 & 5 & 10,000 & 5,000 & Client info. & Theft. & $\begin{array}{l}\text { For profit; caused economic loss to } 3 \text { d co.; obtained } \\
\text { from workplace. }\end{array}$ \\
\hline Wang 2013a & 2013.03 .15 & 王某某 & 7 & 10,000 & $1,000,000$ & Purchase orders. & Purch. & For profit; paid 1,6oo for PIC. \\
\hline \multirow[t]{3}{*}{ Keji 2013} & \multirow[t]{3}{*}{2013.03 .15} & 陈某某 & 6 & 10,000 & $1,000,000$ & \multirow[t]{3}{*}{ Purchase orders. } & \multirow[t]{3}{*}{ Purch. } & \multirow{3}{*}{$\begin{array}{l}\text { The compnay paid } 500 \text { for PIC, presumably for } \\
\text { profit. }\end{array}$} \\
\hline & & 王某某 & 7 & 10,000 & $1,000,000$ & & & \\
\hline & & $\begin{array}{l}\text { 单位某某科技 } \\
\text { 公司 }\end{array}$ & $\mathrm{N} / \mathrm{A}$ & 30,000 & $1, \mathrm{OOO}, \mathrm{OOO}$ & & & \\
\hline Li 2013a & 2013.03 .15 & 李某某 & 14 & 20,000 & 71,158 & Unclear. & Purch. & Sold for profit. \\
\hline Zhang 2013 & 2013.03 .15 & 张某 & 7 & 10,000 & $1,000,000$ & Unclear. & Purch. & For profit; paid 8oo for PIC. \\
\hline \multirow[t]{2}{*}{ Shanghai 2013c } & \multirow[t]{2}{*}{2013.03 .21} & 白某某 & 6 & 10,000 & $1,000,000$ & Purchase orders. & Purch. & For profit; paid 900 for PIC. \\
\hline & & $\begin{array}{l}\text { 上海某某信息 } \\
\text { 科技有限公司 }\end{array}$ & Corp. & 30,000 & $1,000,000$ & Purchase orders. & Purch. & For profit; paid 900 for PIC. \\
\hline Zuo 2013 & 2013.03 .21 & 左某 & 7 & 10,000 & $1,000,000$ & Purchase orders. & Purch. & For profit; paid 900 for PIC. \\
\hline
\end{tabular}




\section{Draft date: Aug. 5, 2015}

\begin{tabular}{|c|c|c|c|c|c|c|c|c|}
\hline Li 2013b & 2013.04 .02 & 李某某 & 9 & 15,000 & $\begin{array}{l}2,259,920 \\
(280,000)\end{array}$ & Unclear. & Purch. & Paid 2,ooo for PIC. \\
\hline $\mathrm{Xu} 2013 \mathrm{a}$ & 2013.04 .18 & 徐某 & 6 & 1,000 & $\begin{array}{l}1,000,000 \\
(280,000)\end{array}$ & Unclear. & Purch. & Paid 500 for PIC. \\
\hline Lu 2013b & 2013.04 .24 & 陆某某 & 4 & 2,000 & 20 & Residency, car, bank, cell location & Purch. & Private investigator/PIC business; sold for profit. \\
\hline Hua 2013 & 2013.04 .28 & 华某 & 12 & 5,000 & $\begin{array}{l}20 \\
\text { individuals. }\end{array}$ & $\begin{array}{l}\text { ID, financial, real estate, bank } \\
\text { account \#, vehicle registration, etc. of } \\
\text { specific individuals }\end{array}$ & Purch. & 50,900 yuan profit. \\
\hline Liu $2013 a$ & 2013.05 .02 & 刘某 & 6 & 10,000 & 32 & Residence; hotel. & Purch. & Private investigator; 38,700 yuan profit. \\
\hline \multirow[t]{4}{*}{ Beijing 2013i } & \multirow[t]{4}{*}{2013.05 .21} & 程某 & 6 & 10,000 & $1,000,000$ & \multirow[t]{4}{*}{ Purchase orders. } & \multirow[t]{4}{*}{ Purch. } & \multirow[t]{4}{*}{ Purcahsed by company for profit. } \\
\hline & & 陈某 & 6 & 10,000 & $1,000,000$ & & & \\
\hline & & 乔某某 & 6 & 5,000 & $1,000,000$ & & & \\
\hline & & $\begin{array}{l}\text { 北京某某创想 } \\
\text { 电子商务有限 } \\
\text { 公司江苏分公 } \\
\text { 司 }\end{array}$ & N/A & 30,000 & $1,000,000$ & & & \\
\hline Wang $2013 \mathrm{C}$ & 2013.06 .08 & 王 a & 6 & 10,000 & 53 & Unclear. & Purch. & Sold for profit. \\
\hline Gao 2013 & 2013.06 .18 & 高某 & 10 & 3,000 & special & $\begin{array}{l}\text { Information on specific individuals } \\
\text { re: location, hotel stay, residence, } \\
\text { enter and exit records, etc. }\end{array}$ & Purch. & 14,500 yuan profit. \\
\hline Guo 2013 & 2013.07 .18 & 郭某某 & 7 & 3,000 & 400 & Unclear. & Acq. & For profit. \\
\hline \multirow[t]{9}{*}{ Ye 2013} & \multirow[t]{9}{*}{2013.07 .30} & 旷某 & 11 & 10,000 & 83,908 & \multirow[t]{9}{*}{ Finance. } & Purch. & Accessory; 130,000 yuan profit. \\
\hline & & 李某 & 11 & 10,000 & 83,908 & & Purch. & Accessory; 110,00o yuan profit. \\
\hline & & 王某 & 11 & 10,000 & 83,908 & & Purch. & Accessory; 100,000 yuan profit. \\
\hline & & 叶某某 & 11 & 10,000 & 83,908 & & Purch. & Accessory; 6o,ooo yuan profit. \\
\hline & & 王某某 & 11 & 10,000 & 83,908 & & Purch. & Accessory; 8o,0oo yuan profit. \\
\hline & & 谭某 & 11 & 10,000 & 83,908 & & Purch. & Accessory; 100,000 yuan profit. \\
\hline & & 叶某某 & 12 & 15,000 & 83,908 & & Purch. & Accessory; 300,00o yuan profit. \\
\hline & & 赵某 & 12 & 15,000 & 83,908 & & Purch. & Accessory; 230,00o yuan profit. \\
\hline & & 叶某 & 12 & 15,000 & 83,908 & & Purch. & Accessory; 230,00o yuan profit. \\
\hline \multirow[t]{4}{*}{ Shanghai 2013b } & \multirow[t]{4}{*}{2013.08 .02} & 徐某 & 9 & 15,000 & \multirow{4}{*}{$\begin{array}{l}3,000,000 \\
(40,000)\end{array}$} & \multirow{4}{*}{\multicolumn{3}{|c|}{$\begin{array}{l}\text { Vice president Xu Mou instructed the head of the information department of the company, Peng Mou, to } \\
\text { purchase a customer list from Number One Website (“一号店网站”). Peng obtained the database account } \\
\text { numbers, passwords, and the server's IP address from Number One Website's employee, Mou Moumou. Peng } \\
\text { then on three separate occasions stole from Number One Website a total of 3,ooo,ooo (40o,ooo after duplicates) } \\
\text { pieces of PIC concerning client order information. Peng also embezzled the funds that were supposed to be } \\
\text { used to purchase the client list. Xu Mou was held liable under a theory similar to respondeat superior. }\end{array}$}} \\
\hline & & 彭某 & 9 & 15,000 & & & & \\
\hline & & 缪某某 & 10 & 15,000 & & & & \\
\hline & & $\begin{array}{l}\text { 上海某某电子 } \\
\text { 商务有限公司 }\end{array}$ & N/A & 30,000 & & & & \\
\hline
\end{tabular}


Draft date: Aug. 5, 2015

\begin{tabular}{|c|c|c|c|c|c|c|c|c|c|}
\hline Chen 2013a & 2013.09 .25 & 陈某某 & 9 & 5,000 & 3,200 & Unclear. & Purch. & \multicolumn{2}{|l|}{ Fraud. } \\
\hline Wu 2013 & 2013.10 .18 & 吴某 & 10 & 5,000 & 918 & Information of specific individuals. & $\begin{array}{l}\text { Purch./investi- } \\
\text { gation. }\end{array}$ & \multicolumn{2}{|l|}{ Private investigator/PIC business. } \\
\hline Wu 2013 & 2013.10 .18 & 郑某 & 10 & 4,000 & 918 & Unclear. & Purch. & \multicolumn{2}{|l|}{ For profit. } \\
\hline Fang 2013 & 2013.11 .01 & 方某 & 9 & $1, \mathrm{OOO}$ & 1,461 & Info on finance, property, infants. & Purch. & \multicolumn{2}{|l|}{ For profit. } \\
\hline Han 2013 & 2013.11 .04 & 韩某 & 12 & 20,000 & 40,161 & $\begin{array}{l}\text { ID, financial, real estate, bank } \\
\text { account \#, vehicle registration, etc. of } \\
\text { specific individuals }\end{array}$ & Purch. & \multicolumn{2}{|l|}{ For profit. } \\
\hline Peng 2012 & 2013.11 .06 & 彭某某 & 6 & 2,000 & 16 (see note) & $\begin{array}{l}\text { Background checks, infidelity, child } \\
\text { behavior monitoring, business } \\
\text { intelligence. }\end{array}$ & Purch. & \multicolumn{2}{|l|}{ Private investigator. } \\
\hline Li $2013 \mathrm{C}$ & 2013.12 .09 & 李某 & 10 & 10,000 & 10,000 & Unclear. & Acq. & \multicolumn{2}{|l|}{ Sold for profit. } \\
\hline Lu 2013 & 2013.12 .19 & 卢某 & EXEMPT & EXEMPT & $\begin{array}{l}1, \text { ooo }+/ 4 \\
\text { pages }\end{array}$ & Contact. & Purch. & \multicolumn{2}{|l|}{ For profit. } \\
\hline Lu 2013a & 2013.12 .19 & 陆某 & EXEMPT & EXEMPT & 50 & Contact. & Purch. & \multicolumn{2}{|l|}{ For profit. } \\
\hline Yao 2013 & 2013.12 .19 & 姚某某 & EXEMPT & EXEMPT & 70 & Contact. & Purch. & \multicolumn{2}{|l|}{ For profit. } \\
\hline Luo 2013 & 2013.12 .23 & 罗某 & EXEMPT & EXEMPT & 100 & Contact. & Purch. & \multicolumn{2}{|l|}{ For profit. } \\
\hline \multirow[t]{5}{*}{ Shanghai 2013a } & \multirow[t]{5}{*}{2013.12 .24} & 汪某 & 16 & 30,000 & \multirow[t]{5}{*}{$6,000,000$} & \multirow{5}{*}{\multicolumn{3}{|c|}{$\begin{array}{l}\text { The corp. def. contracted with Xingye Bank and China Eastern Airlines to market credit cards. } \\
\text { The general manager of the corp. def., Qiao, instructed Shen to meet with an employee of } \\
\text { China Eastern Airlines and purchase 6oo pieces of PIC on members of the "Eastern Miles } \\
\text { Club" for 20o,ooo yuan. It appears the employee did not have authorization to obtain the } \\
\text { information. The PIC was used for the telemarketing activities of the corporate defendant. } \\
\text { Wang Moumou arranged the meeting. Yang Yi was the legal representative of the corporate } \\
\text { defendant and authorized the purchase. }\end{array}$}} & Accessory \\
\hline & & 杨乙 & 18 & 40,000 & & & & & Principal. \\
\hline & & 乔某某 & 20 & 50,000 & & & & & Principal. \\
\hline & & 上海某某 & $\mathrm{N} / \mathrm{A}$ & 200,000 & & & & & \\
\hline & & 沈某 & NONE & NONE & & & & & Accessory \\
\hline Tian 2014 & 2014.01 .15 & 田某某 & 6 & 8,000 & 60,000 & Unclear. & Purch. & \multicolumn{2}{|l|}{ Sold for profit. } \\
\hline \multirow[t]{2}{*}{ Shanghai 2014a } & \multirow[t]{2}{*}{2014.01 .15} & 刘某某 & 9 & 10,000 & 90,000 & Unclear. & Purch. & \multicolumn{2}{|l|}{ For profit. } \\
\hline & & $\begin{array}{l}\text { 上海某某投资 } \\
\text { 管理有限公司 }\end{array}$ & N/A & 15,000 & 90,000 & Unclear. & Purch. & \multicolumn{2}{|l|}{ For profit. } \\
\hline Zhang 2014b & 2014.01 .22 & 张某某 & 6 & 3,000 & 31,000 & Contact. & Theft. & \multicolumn{2}{|c|}{ 1,ooo profit; obtained from workplace. } \\
\hline Shai 2014 & 2014.01 .23 & 邵某某 & 6 & 5,000 & 55,000 & Contact. & Purch. & \multicolumn{2}{|l|}{ For profit. } \\
\hline \multirow{2}{*}{$\begin{array}{l}\text { Shanghai } \\
2014 \mathrm{~b}\end{array}$} & \multirow[t]{2}{*}{2014.01 .23} & 朱某某 & 6 & 5,000 & 60,000 & Unclear. & Purch. & \multicolumn{2}{|l|}{ For profit. } \\
\hline & & $\begin{array}{l}\text { 上海优某某健 } \\
\text { 身管理有限公 } \\
\text { 司 }\end{array}$ & N/A & 20,000 & 60,000 & Unclear. & Purch. & \multicolumn{2}{|l|}{ For profit. } \\
\hline Tang 2014 & 2014.01 .24 & 唐某某 & EXEMPT & EXEMPT & $1,500 / 72$ pages & Contact. & Acq. & & \\
\hline Zhang 2014e & 2014.01 .24 & 张乙 & $\begin{array}{l}\text { NOT } \\
\text { GUILTY }\end{array}$ & $\begin{array}{l}\text { NOT } \\
\text { GUILTY }\end{array}$ & 1,500 & Contact. & Acq. & \multicolumn{2}{|l|}{ Insurance PIC. } \\
\hline \multirow[t]{4}{*}{ Long 2014} & \multirow[t]{4}{*}{2014.02 .13} & 杨某 & 5 & 5,000 & 210,000 & Unclear. & Purch. & & \\
\hline & & 吴某某 & 7 & 10,000 & $3,000,000$ & Unclear. & Purch. & & \\
\hline & & 易某某 & 18 & 20,000 & $100,000,000$ & Unclear. & Purch. & \multicolumn{2}{|l|}{ 4,ooo yuan profit; paid 4,ooo for PIC. } \\
\hline & & 龙某 & 21 & 20,000 & $100,000,000$ & Unclear. & Acq. & 4,000 yuan profit; paid 5,500 fr PIC & \\
\hline
\end{tabular}


Draft date: Aug. 5, 2015

\begin{tabular}{|c|c|c|c|c|c|c|c|c|}
\hline \multirow[t]{2}{*}{ Zhou 2014a } & \multirow[t]{2}{*}{2014.02 .20} & 周某某 & 5 & 1,000 & 7,000 & Unclear. & Purch. & For profit; paid 500 for PIC. \\
\hline & & 汪某某 & 5 & 1,000 & 7,000 & Unclear. & Purch. & For profit; paid 500 for PIC. \\
\hline \multirow[t]{2}{*}{ Zhang 2014d } & \multirow[t]{2}{*}{2014.02 .24} & 杨某某 & 3 & 3,000 & 1,000 & Unclear. & Purch. & For profit. \\
\hline & & 章某某 & 3 & 3,000 & 1,000 & Unclear. & Purch. & For profit. \\
\hline Song 2014 & 2014.02 .27 & 宋某某 & 6 & 1,000 & 35,000 & Unclear. & Acq. & For profit. \\
\hline Gao 2014 & 2014.03 .13 & 高亮 & 4 & 3,000 & 5,000 & Contact. & Purch. & For profit; caused economic loss to $3 \mathrm{~d}$ co. \\
\hline Lu 2014 & 2014.03 .18 & 陆某某 & 15 & 20,000 & $\begin{array}{l}\text { Specific } \\
\text { individuals. }\end{array}$ & Specific individuals. & Purch. & Sold 43,400 yuan profit. \\
\hline Han 2014 & 2014.03 .18 & 李某某 & 16 & 3,000 & 160,000 & Unclear. & Rcpt. & For profit. \\
\hline Liang 2012 & 2014.03 .18 & 梁某某 & 6 & 2,000 & 5,500 & Unclear. & Rcpt. & Sold for 500 yuan profit. \\
\hline Li 2014a & 2014.03 .18 & 李某 & $5+10$ days & 2,000 & 5,500 & Unclear. & Purch. & Sold for profit; paid 500 for PIC. \\
\hline Qian 2014 & 2014.03 .19 & 钱某 & 12 & 2,000 & Individuals. & Information on government officials. & Acq. & $\begin{array}{l}\text { Obtained from public official/police officer; used for } \\
\text { harassment/intimidation. }\end{array}$ \\
\hline Du 2014 & 2014.03 .24 & 杜某 & 6 & 4,000 & 21,017 & Contact. & Acq. & For profit; obtained from workplace. \\
\hline Fan 2014 & 2014.03 .24 & 范某某 & 6 & 2,000 & 339,043 & Contact. & Purch. & For profit. \\
\hline Xing 2014 & 2014.03 .24 & 邢某某 & 12 & 5,000 & 198,187 & Contact. & Acq. & For profit. \\
\hline Chen 2014 & 2014.03 .24 & 陈某某 & 12 & 2,000 & $\begin{array}{l}5,000,000 \\
\text { (数百万条) }\end{array}$ & Unclear. & Trick. & Criminal sale. \\
\hline Tang 2014 & 2014.03 .25 & 唐某某 & 18 & 5,000 & $12,857,019$ & Contact. & Purch. & For profit. \\
\hline Zhou 2014b & 2014.03 .25 & 周乙 & EXEMPT & EXEMPT & 6,175 & Contact. & Purch. & For profit. \\
\hline \multirow[t]{2}{*}{ Mou 2014} & \multirow[t]{2}{*}{2014.04 .02} & 廖某某 & 13 & 5,000 & 50,000 & Unclear. & Purch. & For profit. \\
\hline & & 尹某某 & 13 & 5,000 & 59,000 & Unclear. & Purch. & For profit. \\
\hline Zhang 2014a & 2014.04 .04 & 张某某 & NONE & 4,000 & 16,000 & Contact. & Purch. & For profit. \\
\hline Li 2014b & 2014.04 .09 & 李某某 & 4 & 5,000 & 15,360 & Unclear. & Purch. & For profit. \\
\hline \multirow[t]{6}{*}{ Zhu 2012b } & \multirow[t]{6}{*}{2014.04 .17} & 龙某某 & 10 & 10,000 & 136,727 & Purchase orders. & Rcpt. & Accessory; 100,00o profit. \\
\hline & & 梁某某 & 12 & 10,000 & 136,727 & Purchase orders. & Rcpt. & Accessory; 100,00o profit. \\
\hline & & 殷某某 & 12 & 10,000 & 136,727 & Purchase orders. & Rcpt. & Accessory; 100,000 profit. \\
\hline & & 陈某某 & 12 & 10,000 & 136,727 & Purchase orders. & Rcpt. & Accessory; 100,000 profit. \\
\hline & & 朱某某 & 18 & 30,000 & 136,727 & Purchase orders. & Rcpt. & Principal; 100,000 profit. \\
\hline & & 徐某某 & 18 & 30,000 & 136,727 & Unclear. & Acq. & Principal; 100,00o profit. \\
\hline \multirow[t]{6}{*}{ Yang 2014} & \multirow[t]{6}{*}{2014.04 .24} & 曹某 & 4 & 10,000 & 6,000 & \multirow{6}{*}{$\begin{array}{l}\text { Public exam candidate info. } \\
\text { In this case, Yang Mou, the vice } \\
\text { president of an education technology } \\
\text { company, conspired with Xu Jia to } \\
\text { use the PIC of public exam } \\
\text { candidates to recruit new students } \\
\text { and make a profit. Yang used his } \\
\text { position in the company to provide }\end{array}$} & Purch. & For profit. \\
\hline & & 廖某 & 6 & 20,000 & 13,000 & & Purch. & For profit. \\
\hline & & 邵某某 & 6 & 20,000 & 25,000 & & Purch. & For profit. \\
\hline & & 陈甲 & 7 & 20,000 & 50,000 & & Purch. & Sold for profit. \\
\hline & & 李丙 & 8 & 100,000 & 50,000 & & Purch. & Sold for profit. \\
\hline & & 李乙 & 9 & 30,000 & 50,000 & & Purch. & Sold for profit. \\
\hline
\end{tabular}




\section{Draft date: Aug. 5, 2015}

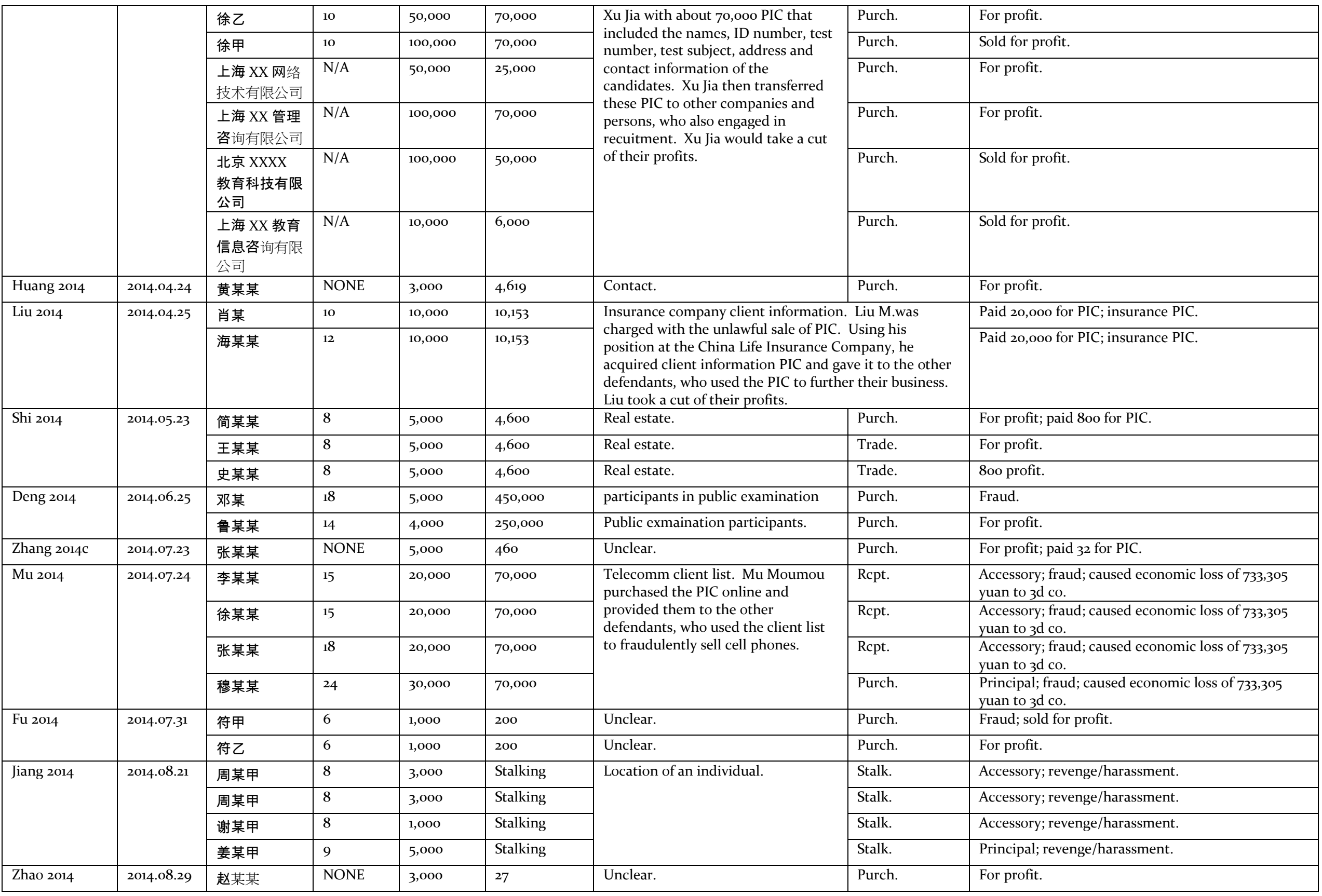

